\title{
ДЕТЕРМИНАНТЫ ДЕМОГРАФИЧЕСКОГО ПЕРЕХОДА НА ГЛОБАЛЬНОМ ЮГЕ
}

\author{
СЕРГЕЙ ИВАНОВ
}

\begin{abstract}
Все страны глобального Севера прошли демографический переход, большинство из них стоят на пороге неминуемой депопуляции. В течение последних двух десятилетий к ним присоединились три десятка стран глобального Юга (включая Китай) с совокупным населением в 1,5 млрд чел. Некоторые развивающиеся страны разных континентов (в том числе Индия) находятся в продвинутых фазах перехода, в то время как в Африке к югу от Cахары, в том числе в многонаселенной Нигерии, рождаемость остается на очень высоком уровне. Демографический взрыв в регионе еще долго не будет погашен, к кониу столетия население может увеличиться еще на 1,8-4,5 млрд человек, что чревато разрушительными последствиями. Снижение детской смертности и модернизация образа жизни порождают прокреативное целеполагание и формируют механизмы адаптации рождаемости к фоновому уровню и индивидуальному опьту детской смертности, а также снижают плодовитость. Эта трансформаџия создает условия для снижения рождаемости. Тренд снижения зависит от динамики числа желаемых (выживщих) детей $u$ возможностей реализации этого желания. Прокреативная цель является функцией сочиальноэкономических факторов, включая образование, занятость, урбанизацию, а также не всегда поддающихся количественному выражению институциональных и экологических условий. Современная контрацепция является эффективным способом достижения прокреативной цели. Пробуксовывание демографического перехода во многих странах Африки к югу от Сахары обусловливается неблагоприятными значениями всех факторов рождаемости, а продолжение демографического взрыва приведет к тяжельм последствиям.
\end{abstract}

Ключевые слова: демографический переход, рост населения, демографическое равновесие, детская смертность, репродуктивное поведение, страховое поведение, замещаютее поведение, рождаемость, плодовитость, контрацепция, планируемое родительство, образование, урбанизация, демографическая политика, Африка к югу от Cахары.

\section{КОНЦЕПЦИИ ДЕМОГРАФИЧЕСКОГО ПЕРЕХОДА}

За последние полтора столетия кардинальные изменения в демографическом воспроизводстве произошли во всех странах мира. Они начались в большинстве европейских стран и США во второй половине XIX века и спустя столетие распространились на Латинскую Америку, затем Азию и Северную Африку, но находятся на ранней стадии в Африке к югу от Сахары.

СЕРГЕЙ ФЕЛИКСОВИЧ ИВАНОВ (serguey.ivanov@yandex.ru), НЕЗАВИСИМЫЙ ЭКСПЕРТ, РОССИЯ.

СТАТЬЯ ПОСТУПИЛА В РЕДАКЦИЮ В МАРТЕ 2017 Г. 
Эти изменения, называемые демографическим переходом и заключающиеся в снижении смертности и радикальной перестройке репродуктивного ${ }^{1}$ поведения, представляют собой, наряду с урбанизацией и индустриализацией, мощнейший за всю человеческую историю модернизационный сдвиг [Вишневский 2014], формирующий новый «демографический метаболизм» [Hirschan 1994].

Концепция демографического перехода, ставшая центральной в демографии XX века, объясняет снижение смертности и рождаемости с высоких уровней, типичных для традиционных бедных обществ, к низким уровням, свойственным современным богатым обществам. Она породила обширную литературу, в которой эмпирические измерения факторов демографической динамики опираются на концептуальные объяснения причин снижения смертности и рождаемости и в свою очередь их питают. Строго говоря, концепция демографического перехода должна включать оба компонента воспроизводства населения, однако для фокусировки анализа нередко под демографический переходом понимается трансформация рождаемости, в то время как трансформация смертности описывается концепцией эпидемиологического перехода. Оба компонента воспроизводства тесно взаимосвязаны через детскую смертность, что глубоко понимал основоположник идеи эпидемиологического перехода [Омран 1977]. Концепции демографического перехода в указанном узком смысле и эпидемиологического перехода непротиворечивы и взаимодополняемы. С другой стороны, можно считать, что в отношении детской смертности эпидемиологический переход непосредственно входит в предмет «узкой» концепции демографического перехода, а смертность взрослых не входит. Хотя эти соображения кажутся начетническими, они могут быть полезными, предостерегая от забвения ключевой роли снижения детской смертности в трансформации репродуктивного поведения во время демографического перехода, особенно на глобальном Юге 2 .

Теория демографического перехода объясняет снижение рождаемости трансформацией репродуктивного поведения вследствие изменения количественной потребности в детях и возможностей ее удовлетворения. Вследствие этого расточительный тип демографического равновесия (высокая рождаемость балансирует высокую смертность) сменяется эффективным (низкая рождаемость при низкой смертности). Это равновесие соответствует стационарному населению. По отношению к изменению гомеостатических механизмов царит согласие, что имеет очень большое прикладное

\footnotetext{
${ }^{1}$ Репродукция и прокреация близки по значению, хотя в контексте данной проблематики можно усмотреть различие и счесть его существенным. Между тем в данной статье эти слова и их производные считаются полными синонимами, чье использование в том или ином случае определяется стилистическими предпочтениями автора.

2 Понятие глобального Юга используется как синоним совокупности развивающихся стран. Подразделение всех стран мира на развитые (глобальный Север) и развивающиеся вошло в обиход Организации Объединенных Наций в начале 1950-х годов. Все страны Европы, а также Австралия, Канада, Новая Зеландия, США и Япония классифицируются как развитые, а все остальные - как развивающиеся. Уже тогда имелись несоответствия между этой классификацией и истинным уровнем развитости отдельных стран: Албания и Молдавия (в ретроспективе) считались и считаются развитыми, а Аргентина и Израиль - развивающимися. С тех пор географическая принадлежность и уровень развития разошлись еще больше (но все же не очень сильно), так как ряд стран Азии (например, Южная Корея и Сингапур) и Латинской Америки (Бразилия, Мексика) экономически обогнали замыкающую группу европейских стран. Однако в практике ООН эта бинарная классификация сохраняется, являясь, строго говоря, географической, а не экономической.
} 
значение, ибо этот постулат положен в основу демографического прогнозирования, системного моделирования экономических и экологических процессов и демографической политики.

Варианты концепции демографического перехода различаются детерминантами изменений репродуктивного поведения. В отношении рождаемости различия между детерминантами не очень многообразны, но благодаря обилию исследований кажутся настолько глубокими, что возникает соблазн считать концепцию демографического перехода не единым конструктом, а континуумом конкурирующих теорий. В этом континууме есть два полюса. На одном - представление о совокупности многих социальнодемографических факторов, определяющих контекст репродуктивного поведения и его радикальную трансформацию в процессе перехода. На другом - сведение перехода к адаптации репродуктивного поведения к новым условиям снизившейся детской смертности; при этом оказывается, что адаптация на микроуровне семьи тождественна адаптации популяции. Таким образом, единственным теоретически значимым детерминантом снижения рождаемости в процессе демографического перехода является рост доживаемости детей, а прочие факторы оказываются в принципе избыточными. В этом вопросе сложилась необычная гносеологическая картина. В то время как в общественных науках концепции, как правило, развиваются от простого к сложному, в отношении демографического перехода в некотором смысле имеет место противоположная тенденция. Точнее, происходит бифуркация: генеральной тенденцией остается социальнодемографический подход, а демографический подход предлагает альтернативную методологию, причем весьма интересную.

Представление о многофакторной социально-экономической детерминации демографического перехода было заложено основателями теории ${ }^{3}$. В формулировке Ландри типы воспроизводства населения (демографические режимы) являются функцией материальных потребностей индивидов и производственных потенциалов экономических систем. В «примитивном» демографическом режиме, типичном для экономической системы натурального производства, экономические факторы обусловливают уровень смертности, но не рождаемости, а численность населения стремится к максимуму, который может обеспечить экономическая система. В этом режиме фоновые уровни смертности и рождаемости высоки, а медленный рост населения часто прерывается сильными вспышками сверхсмертности. «Промежуточный» режим присущ обществам, в которых научный прогресс делает эффективной борьбу со смертью, а экономический прогресс повышает уровень жизни, который население стремится поддержать или повысить. Это стремление приводит к некоторому ограничению рождаемости путем распространения позднего вступления в брак и безбрачия. «Современный» демографический режим зарождается тогда, когда высокая эффективность производства формирует массовые индивидуальные установки на достижение высокого уровня жизни и его постоянный рост. Их реализация требует сознательного ограничения рождаемости (включая добровольную

3 Хотя термин «демографический переход» был предложен американским демографом Ф. Ноутстайном [Notestnein 1945], эскиз концепции был предложен ранее французским демографом А. Ландри [Landry 1909; 1936], который чаще использовал термин демографическая революичи, и американским демографом У. Томпсоном [Thompson 1929]. 
бездетность), что осуществляется, как и прежде, косвенно через поздние браки и безбрачие, но также и прямо с помощью контрацепции.

В поле исследований находятся факторы, различные по уровню в социальной системе, которые обычно полагаются главными, стержневыми в детерминации демографического перехода (падение детской смертности, урбанизация, образование, женский и детский труд, потоки благ в домохозяйстве, использование контрацепции). Обычно явно демонстрируется или по умолчанию предполагается, что эти факторы однонаправлены и действуют как «прямо» (например, детская смертность $\rightarrow$ рождаемость, образование $\rightarrow$ рождаемость, использование контрацепции $\rightarrow$ рождаемость), так и опосредованно (например, урбанизация $\rightarrow$ образование $\rightarrow$ смертность $\rightarrow$ рождаемость), а также как «по отдельности» (например, использование контрацепции $\rightarrow$ рождаемость наряду с вовлечением женщин в наемный труд $\rightarrow$ рождаемость), так и сообща, интегрированно, как в схеме смены межпоколенных потоков благ [Caldwell 1982; 2001]. Полученные на этом поле эмпирические результаты постоянно реплицируются, ракурсы меняются, объектами анализа бывают страны, суб- и транснациональные общности, семьи и индивиды. В результате иногда удается нащупать социокультурную специфику стран и регионов, реже - внятно интегрировать ее в количественный демографический анализ. Например, оказывается, что типы семейной организации, очень разные в странах Юга, оказывают влияние на демографический переход: так, в африканских обществах широко распространена экстернализация (на родственников) ресурсных затрат на содержание и воспитание детей. С другой стороны, в сельской местности детский труд не только важен для родителей, но в условиях растущего дефицита воды и обезлесения его значение возрастает. Наконец, традиционные системы землепользования в условиях обилия малоплодородной земли заставляют ценить многодетность.

На противоположном полюсе континуума - концепция замкнутой (системной) демографической динамики, требующая от населения изменить господствующую репродуктивную стратегию для того, чтобы сделать ее адекватной сократившейся смертности. Другие социальные факторы, опосредующие, усиливающие или купирующие это влияние, полагаются избыточными, затеняющими главное в перестройке воспроизводства населения. Современная интерпретация заявляет, что «многослойный пирог» социально-экономических концепций демографического перехода заслоняет его всеобщую суть как коренной трансформации режима воспроизводства населения, которая «меняет репродуктивную стратегию вида Homo sapiens» [Вишневский 2014]. Как будет показано ниже, детская смертность действительно является sine qua non перестройки репродуктивного поведения, главным, хотя и не единственным, фактором снижения рождаемости. Сначала возросшая выживаемость детей играет роль абсолютно необходимого триггера перестройки. Это предположение хорошо согласуется с наблюдением, что снижение рождаемости следует за началом снижения смертности не немедленно, а с некоторым лагом длительностью от нескольких лет до десятилетий. Действительно, для того, чтобы не обладающие демографическими познаниями люди осознали, что выживаемость детей выросла, необходима некая критическая масса перемен. Вероятно, величина лага положительно зависит от допереходного уровня детской смертности и отрицательно - от темпов ее снижения. Впоследствии, т.е. во время самого 
демографического перехода, траектории рождаемости и смертности сближаются. Указанный лаг и последующий угол наклона тренда рождаемости относительно тренда детской смертности определяют масштабы и длительность ускоренного роста населения, т.е. мощность демографического взрыва.

Вторым компонентом системной динамики является представление о том, что репродуктивные стратегии популяций и индивидов тождественны и направлены на достижение и сохранение равновесия, сводящегося к стационарности, т.е. простому воспроизводству населения. Гомеостатический механизм нацелен на поддержание роста населения в некоей полосе оптимальности, т.е. не допускает ни превышения емкости среды обитания, ни депопуляции. Идея о гомеостатической природе демографического воспроизводства интересна как изящной простотой, так и яркостью, с которой она подчеркивает значение демографического перехода (революции) во всемирной истории. Вместе с тем у этого подхода есть уязвимые места.

Само представление о стремлении к демографическому равновесию, понимаемому как стационарность численности (и возрастной структуры) населения, расходится с реальностью. Человечество размножалось на протяжении всей своей истории, хотя и медленно, а порой прерывисто. Иначе как бы к началу глобального демографического перехода население мира перевалило за 1,5 млрд чел. Развивающиеся страны, да и то далеко не все, стали втягиваться в демографический переход на столетие позднее стран Севера (за исключением нескольких латиноамериканских стран, в том числе Аргентины, где переход начался на рубеже веков). В то время вероятность дожития женщин до среднего возраста рождения детей составляла 0,60, суммарный коэффициент рождаемости - 6-7 детей на женщину, а в некоторых странах Африки к югу от Сахары и Западной Азии и выше. Таким образом, нетто-коэффициент воспроизводства составлял 1,8 в Азии и Африке и 2,2 в Латинской Америке, т.е. был вдвое выше, чем нужно для простого воспроизводства. Чтобы при такой рождаемости нетто-коэффициент воспроизводства был близок к единице, детская смертность в начале демографического перехода должна была быть примерно вдвое более высокой, чем реально наблюдавшаяся около 1950 г. [United Nations 2017] ${ }^{4}$. Это выглядит маловероятным, да и не подтверждается ни эмпирическими данными, ни теоретической проработкой этого вопроса.

С другой стороны, хотя тренды рождаемости и смертности в большинстве развивающихся стран в начале XXI века таковы, что нетто-коэффициент там действительно стремится к единице, следует иметь в виду, что в странах Севера после прохождения кратковременного этапа простого воспроизводства в 1970-1980-х годах суммарная рождаемость опустилась ниже двух детей на женщину (дефицит рождений находится в интервале 0,1-1,0 детей на женщину), а нетто-коэффициент соответственно упал намного

${ }^{4}$ Длинные (с 1950 г.) ряды демографических показателей по всем странам мира каждые два года пересматриваются Отделом народонаселения Секретариата ООН для того, чтобы интегрировать новые знания и применить новые методики. Не будет преувеличением утверждать, что эти оценки, основанные на анализе всей совокупности имеющихся данных и постоянно совершенствующихся моделях, дают наилучшую из существующих интегрированную картину демографических процессов в мире, включая страны с дефицитом надежной информации. Источником приводимых в тексте демографических показателей является по умолчанию последний пересмотр демографических оценок и прогнозов ООН [United Nations 2017]. 
ниже единицы. Депопуляция, уже начавшаяся в Германии, Италии, Польше и России, в течение полутора-двух десятилетий неминуемо охватит практически весь глобальный Север (за исключением Новой Зеландии). К настоящему времени уже более трех десятков развивающихся стран «проскочили» порог простого воспроизводства. В Китае это произошло более десятилетия назад, и через несколько лет начнутся колебания, а впоследствии - устойчивое сокращение численности населения страны. Непохоже, что это - отклонения от всемирно-исторического процесса. Представляется, что суженное воспроизводство населения - типичный постпереходный этап демографического развития, обусловленный совокупностью социальных факторов, которых не было или которые были иррелевантны для репродуктивного поведения в допереходных и переходных обществах [United Nations 2003].

Концепция глобального равновесия предлагает разрешить указанное противоречие, отказавшись от национального и даже регионального подходов: объектом наблюдения должен быть весь биологический вид - человечество в планетарном масштабе. Такой взгляд намеренно игнорирует неодинаковость детерминант репродуктивного поведения до, во время и после перехода, а также социокультурные различия между «глобальными субпопуляциями» в каждой из этих фаз, вытекающую из них дисперсию уровней рождаемости и, следовательно, динамики населения и ее последствий. Другим допущением является гипотеза о том, что «все образуется» и в перспективе одного-двух столетий население мира стабилизируется либо путем выравнивания воспроизводства всех национальных популяций на уровне стационарности, либо депопуляция одной части мира будет компенсировать рост населения в другой.

Эти допущения порождают два контраргумента. Во-первых, даже если глобальное равновесие наступит в очень отдаленной перспективе, это не гарантирует бесконфликтное развитие в течение периода стабилизации. Низкая и сверхнизкая рождаемость в странах, завершивших демографический переход, уже порождает проблемы, географические масштабы и глубина которых непременно возрастут. Еще серьезнее перенаселение, в особенности в странах и регионах, где рождаемость еще высока. Чтобы уравновесить депопуляцию и старение населения как Севера, так и «новых» постпереходных стран Юга продолжающимся демографическим взрывом, надо было бы увеличить миграционные потоки из Африки в десятки и сотни раз, что вряд ли реалистично. Во-вторых, само утверждение о целевой стационарности логически представляет собой круговой аргумент. Неотвратимость всеобщего распространения и закрепления индивидуальных репродуктивных стратегий, приводящих к усредненной двухдетности, выводится из необходимости обеспечения простого воспроизводства населения. Характерно, что вплоть до начала 2000-х годов центральный вариант демографических прогнозов ООН исходил из гипотезы, что именно это и произойдет повсеместно к концу XXI века путем линейного выхода траекторий суммарного коэффициента рождаемости на уровень 2,05-2,10 ребенка на женщину. Впоследствии обобщение новых наблюдений привело к выводу, что демографическая реальность вряд ли будет развиваться по этому сценарию; прогнозные модели были пересмотрены с тем, чтобы учесть разнообразие условий; в результате получена значительная дисперсия уровней рождаемости на горизонте прогноза. 
Если сводить демографический переход к автоматической адаптации рождаемости к снизившейся смертности, вопросы временных лагов между этими процессами и различий в скорости адаптации имеют лишь прикладное, но не теоретическое значение. Между тем национальные особенности трансформации демографического метаболизма определяют хоть и временное, но подчас огромное ускорение роста населения, которое в некоторых странах может привести к коллапсу не только национального, но и регионального, а то и глобального масштаба (не в слабом варианте Мальтуса, а по катастрофическому сценарию "Пределов роста" [Meadows et al. 1972; Meadows et al. 2004]). Во второй половине XX века в странах Юга это ускорение было так велико, что породило вошедшую во все языки метафору «демографический взрыв» (рисунок 1). Теория не должна оставаться равнодушной к тому, что за 65 лет в Индии и Китае население утроилось, в Африке к Югу от Сахары выросло более чем впятеро, а в некоторых странах в 8 раз (только за счет естественного прироста), в то время как в развитых странах увеличилось лишь наполовину. Несмотря на прекращение демографического взрыва в большинстве развивающихся регионов, в Африке к югу от Сахары его потенциал настолько высок, что многократное увеличение численности населения более чем вероятно.

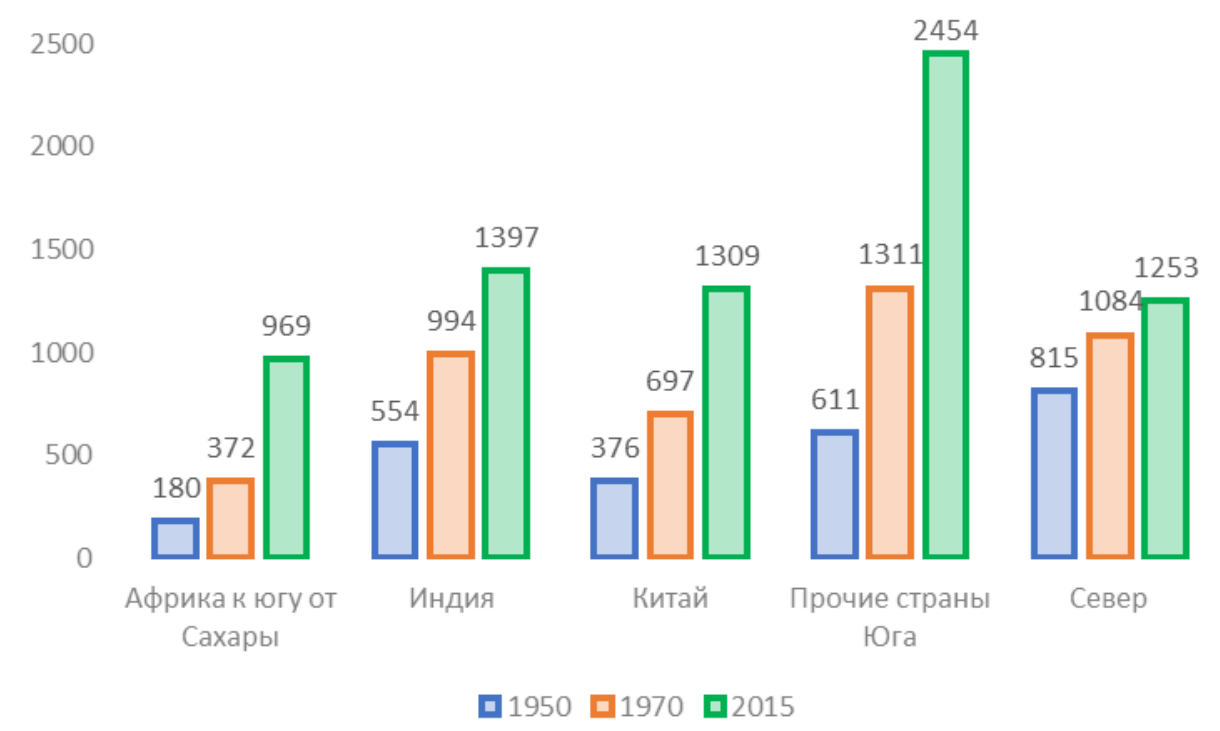

Рисунок 1. Численность населения групп стран, 1950-2015, млн человек

Источник: [United Nations 2017: POP/1-1].

Если оставить за скобками идею равновесия или связывать его не со стационарностью, а с такой демографической динамикой, которая удовлетворяет неким внешним меняющимся условиям - их иногда называют емкостью среды обитания (по ее определению и тем более количественным параметрам вряд ли когда-либо удастся достичь устойчивого консенсуса), - оказывается, что между «репродуктивной стратегией вида» и многофакторным репродуктивным поведением есть не непреодолимое противоречие, а взаимодополняемость. Коренное улучшение выживаемости детей в принципе меняет механизм принятия репродуктивных решений. Без снижения детской смертности демографический переход состояться не может. Культурно-институциональные и социально-экономические факторы способствуют перестройке репродуктивного поведения или ей препятствуют. Препятствия могут даже блокировать переход (точнее, изменения его 
прокреативного компонента), что включит некие положительные механизмы адаптации и коррекции, которых может хватить для возвращения к тренду приближения к равновесию, а может и не хватить, что чревато большими неприятностями.

\section{ПАРАМЕТРЫ СВЯЗИ РОЖДАЕМОСТИ С ДЕТСКОЙ СМЕРТНОСТЬЮ5}

Снижение рождаемости вслед за снижением детской смертности является главным механизмом демографического перехода. Эта связь отчетливо проявляется как в реальных, так и в условных поколениях. В условиях, когда женщины теряют 30\% рожденных ими детей, среднее итоговое число рождений оказывается близким к 6, а когда выживают практически все дети, среднее итоговое число рождений составляет около $2,5^{6}$. Теснота связи детской смертности и рождаемости в период 1950-2015 гг. (т.е. для 66 пар наблюдений), превышает 0,75 в 120 странах, в том числе в 70 странах она больше 0,90 (таблица 1). Связь, оцененная «поперечно» для каждого года в интервале 1950-2015 гг. по всем 163 странам, менее тесна, но непрерывно, хотя и нелинейно, усиливается с 0,48 в 19501955 гг. до 0,87 в 1995-2000 гг. ${ }^{7}$ Объяснение расхождения в тесноте связи рождаемости с детской смертностью между поперечным и продольным измерениями может крыться в систематических межстрановых различиях институциональных факторов рождаемости, в том числе названных в предыдущем разделе. Тот факт, что именно в Африке к югу от Сахары корреляция существенно слабее, чем в других регионах, говорит в пользу этого объяснения.

Таблица 1. Распределение развивающихся стран по коэффициенту корреляции между детской смертностью и суммарной рождаемостью в 1950-2015 гг., число стран

\begin{tabular}{lcc|c|c|c}
\hline & $>0,90$ & $0,75-0,89$ & $0,50-0,74$ & $0,00-0,49$ & $<0,00$ \\
\hline Азия & 15 & 11 & 4 & 0 & 1 \\
Латинская Америка & 31 & 5 & 2 & 0 & 0 \\
Ближний Восток и Северная Африка & 10 & 19 & 4 & 1 & 0 \\
Океания & 7 & 3 & 1 & 0 & 0 \\
Африка к югу от Сахары & 7 & 12 & 15 & 11 & 5 \\
\hline
\end{tabular}

Источник: [United Nations 2017].

Корреляционная связь между детской смертностью и рождаемостью настолько тесна именно потому, что детская смертность является мощнейшим фактором рождаемости, а

\footnotetext{
${ }^{5}$ Речь идет о младенческой (на первом году жизни) и ранней детской (в возрастном интервале 1-4 года) смертности, т.е. о смертности детей до достижения пятилетнего возраста. В принципе, как детерминант репродуктивного поведения можно рассматривать доживаемость до окончания детства (например, до 15летнего возраста). Против этого, однако, есть три возражения. Во-первых, соответствующие данные по развивающимся странам редки и ненадежны. Во-вторых, чем дольше прожил ребенок, тем меньше его смерть влияет на последующее репродуктивное поведение хотя бы в силу возрастных ограничений прокреации. Втретьих, в условиях высокой смертности пятилетний возраст (а при низкой смертности - окончание младенчества) является порогом, за которым возрастная смертность резко падает и на протяжении многих лет жизни остается на низком уровне.

6 Рассчитано по данным 146 медико-демографических обследований (Demographic and Health Surveys), проведенных в 74 развивающихся странах с 1986 по 2004 г. Параметры рассчитаны на основе ответов замужних или состоявших ранее в браке 45-49 летних женщин на вопросы об общем числе рождений и выживших детях.

${ }^{7}$ Коэффициенты корреляции рассчитаны по [United Nations 2017: MORT/1-2, FERT/4].
} 
также потому, что снижение детской смертности было воистину революционным, всеобщим и необратимым. Только геноцид 1975-1979 гг. в Камбодже и 1994 г. в Руанде вызвал крутые всплески смертности, хотя тяжелые времена бывали и во многих других развивающихся странах. Даже в наименее развитых странах ${ }^{8}$ детская смертность в 19502015 гг. снизилась с 345 до 80 смертей на 1000 родившихся, а в среднем по остальным развивающимся странам - с 250 до 48 смертей. Это, впрочем, не означает, что страны шли единым фронтом. Во-первых, исходные (в середине XX века) национальные уровни очень сильно различались: от 428 в Мали до 64 в Уругвае. Во-вторых, были значительные перепады в скорости снижения детской смертности: от 68\% в Африке к югу от Сахары до 93\% в Восточной Азии. Это привело к широкому диапазону нынешних уровней: от 2-9 промилле в 18 странах Азии и Карибского бассейна до 100-156 промилле в 18 странах Африки к югу от Сахары [United Nations 2017].

Итак, есть основания считать, что поскольку на макроуровне популяций доживаемость детей (детская смертность) тесно связана с рождаемостью, то масштабное снижение детской смертности влечет за собой коренные изменения рождаемости. Эта перестройка не является непосредственно популяционной, как было бы, если лишь изменения соотношения групп с разной рождаемостью определяли усредненную динамику ее уровня. Главным мотором перестройки воспроизводства населения стало массовое (если не сказать всеобщее) и коренное изменение репродуктивного поведения.

\section{РОЛЬ СНИЖЕНИЯ СМЕРТНОСТИ В СТАНОВЛЕНИИ ПЛАНИРУЕМОГО РОДИТЕЛЬСТВА9}

Снижение детской смертности является триггером и главным детерминантом перестройки демографического поведения в начальной фазе перехода [Schultz 1976; Preston 1978]. Снижение смертности и рождаемости идут рука об руку в течение всей основной фазы демографического перехода, хотя зависимость постепенно ослабевает. В современном типе воспроизводства населения с его очень низкой детской смертностью ее влияние на

8 Статус наименее развитой страны определяется Генеральной Ассамблеей ООН по представлению правительства в случае, если страна удовлетворяет некоторым условиям, перечень и структура которых систематически пересматриваются. В 1971 г., когда был введен этот статус, в группу наименее развитых стран входили 24 государства. С тех пор столько же развивающихся стран вошло в эту группу и лишь одна страна ее покинула. В целях сопоставимости демографических оценок состав группы считается постоянным (47 стран).

9 Поскольку на этапе низкой и очень низкой детской смертности она перестает определять репродуктивное поведение, большая часть соответствующей литературы по западным странам относится к прошлому. Демографические исследования этой проблематики в развивающихся странах были проведены в основном в 1970-1990-е годы. Тогда были раскрыты основные темы и получены ответы на главные вопросы. Впоследствии было опубликовано сравнительно мало заметных работ в этой области. Вызывает удивление, что тема воздействий детской смертности на рождаемость не нашла своего места в программе разработки Demographic and Health Surveys (DHS), хотя в этой уникальной по географическому охвату и продуманности вопросов серии обследований получен большой объем релевантной информации. В российской демографии эта проблематика разработана мало. Опубликованные автором в 1987-1988 гг. работы [United Nations 1987; Lloyd, Ivanov 1988] могут быть полезны отечественным исследователям, в том числе потому, что концептуальные схемы, разработанные тогда, не были опровергнуты, а население Юга составляет 6,2 из 7,4 млрд человек, живущих на Земле. Они изложены ниже с привлечением новых данных, которые подтверждают выводы, полученные три десятилетия назад. 
рождаемость стало ничтожным. Но еще несколько десятилетий назад выживание детей было серьезным фактором, формирующим репродуктивное поведение в развитых странах [Иванов 2015].

Повышение выживаемости детей воздействует на репродуктивное поведение через четыре различных механизма, каждый из которых приводит к снижению рождаемости. Физиологический механизм обеспечивает снижение рождаемости в ответ на снижение детской смертности даже в отсутствие сознательного регулирования деторождения. Вследствие улучшения выживаемости детей конечный результат прокреации становится предсказуемым, что является непременным условием для планирования семьи ${ }^{10}$. Это делает возможным ощутить и осознать долговременные риски потерять одного или нескольких детей и заранее застраховаться от таких рисков рождением большего числа детей. Другой формой адаптации к детской смертности является замещение умершего ребенка дополнительным рождением. Развитие указанных механизмов хронологически последовательно, но фазы накладываются, в результате чего они часто сосуществуют. По отдельности и в совокупности эти механизмы (кроме физиологического) являются репродуктивными стратегиями - основой планируемого родительства.

Исторически первый, физиологический, механизм заключается в удлинении интервалов между рождениями в популяции, практикующей грудное вскармливание и особенно традиционное послеродовое сексуальное воздержание. Для этого механизма не нужен демографический переход; более того, он сильнее всего проявляется в условиях естественной рождаемости и слабеет по мере распространения практики планирования семьи. Главным признаком «естественной» рождаемости допереходных обществ является отсутствие целенаправленного регулирования деторождения в зависимости от числа уже рожденных детей. В населении, не практикующем сознательного ограничения рождаемости, итоговое число детей эквивалентно накопленной сумме взаимонезависимых интергенетических интервалов, охватывающих весь репродуктивный период жизни женщины. В таком населении изменения интервалов непосредственно претворяются в изменения уровня рождаемости. Иными словами, женщина, потерявшая за свою жизнь больше младенцев, родит больше детей, а снижение детской смертности оборачивается падением итоговых показателей рождаемости условных и реальных поколений. Часто встречается довольно сильный физиологический эффект, когда выживание одного дополнительного ребенка приводит к снижению итоговой рождаемости на 0,25-0,30 ребенка [Preston 1978]. Особенно яркий эпизод наблюдался в начале 1960-х годов в Гамбии, где эпидемия вызвала резкий всплеск смертности. Год спустя после подъёма коэффициента детской смертности на 20 процентных пунктов рождаемость удвоилась, а еще через год вернулась к своему докризисному уровню [Thompson 1975].

Означает ли естественная рождаемость, что родителям безразлично, сколько их детей выживет, или родители всегда стремились к максимизации потомства? В действительности ни тот, ни другой типы поведения не были универсальны. Родить и вырастить ребенка всегда требует немалых затрат и отвлекает ресурсы от их

10 Термины «планирование семьи», «внутрисемейное планирование рождаемости» и «планируемое родительство» тождественны и описывают целенаправленное регулирование деторождения индивидами. 
альтернативного использования. Допереходные общества различались источниками этих затрат (например, родители или расширенная семья), а также правилами наделения капитальными ресурсами (прежде всего землей). К примеру, в России крестьяне растили детей только на свои средства, получали земельный надел только на сыновей и должны были отдавать в приданое дочерям значительные суммы. В этих условиях расходы на детей могли перевешивать долгосрочные ожидания больших доходов от них. Соответственно многодетность многими не приветствовалась [Демографическая модернизация... 2006: 2943]. С другой стороны, если большая часть расходов по воспитанию ребенка обеспечивается родней, а земельные ресурсы представляются неограниченными (как это часто бывает в Африке к югу от Сахары), каждый выживший ребенок будет представлять собой ценное приобретение, а не экономическую нагрузку.

Особенности поведения родителей могут играть роль в значительных колебаниях детской смертности в условиях естественной рождаемости. При этом речь идет не о различной степени знания правильных навыков ухода за детьми, профилактики и лечения детских болезней, а о сознательном избирательном уходе за детьми различного пола и очередности рождения. По всем районам мира имеются исторические или современные данные по систематическому инфантициду, подкидыванию, лишению заботы, избирательному питанию и медицинскому обслуживанию детей [Вишневский 2005; Dickeman 1975; Shorter 1977; Scrimshaw 1983] и применению запретных (не санкционированных культурой) практик регулирования деторождения [Демографическая модернизация... 2006: 29-43]. Инфантицид практиковался на протяжении всей человеческой истории, но уже в 1980-е годы официальный запрет практически повсеместно изжил эту практику. С другой стороны, различные формы дифференциальной дискриминации в питании, уходе, лечении распространены и в наше время. Демографические и исторические источники приводят многочисленные примеры подкидывания детей в Европе XVII-XIX веков [Shorter 1977].

Избирательный уход, заключающийся в дискриминации менее ценных или нежелательных детей, является, вероятно, наиболее типичной формой контроля за выживанием в условиях естественной рождаемости. Многочисленные обследования 1960 1970-х годов показывали, что в ближневосточных и южноазиатских странах с сильно выраженной сегрегацией женщин родители систематически предпочитали мальчиков во всех сферах семейной жизни, включая питание, что приводило к соответствующим различиям в смертности. Практика избирательного ухода отмирает: медикодемографические обследования 1980-2000-х годов, проведенные в 70 развивающихся странах, не показывают статистически значимой разницы между мальчиками и девочками в питании, лечении и смертности. Эти же обследования показывают, что замеченные в прошлом различия в питании, лечении и смертности между детьми различной очередности рождения сохраняются, хотя и в существенно ослабленном виде [United Nations 1987].

Между тем и избирательный уход, и подкидывание (или отказ от родительства), и инфантицид - вне зависимости от степени соответствия такого поведения превалирующим этическим нормам и закону - демографически и экономически малоэффективны, ибо представляют собой коррекцию уже достигнутого репродуктивного результата, а ресурсы по уходу за ребенком, которым родители впоследствии пожертвуют, оказываются 
непроизводительной затратой. Мало того, очень высокая детская смертность предопределяет непредсказуемость итогового числа детей. В этих условиях отбор детей для избирательного ухода может не совпадать с их врожденной выносливостью, что уменьшит шансы достижения желаемого репродуктивного результата.

Высокая и сильно колеблющаяся смертность делала невозможным для родителей хоть сколько-нибудь надежно предсказать, сколько детей выживет из данного числа рожденных. С другой стороны, в таких условиях существует не столь многодетность, сколь многорождаемость [Демографическая модернизация 2006: 29-43]. Снижение детской смертности с очень высоких и колеблющихся уровней создает фундаментальное условие для превращения прокреации в регулируемое и эффективное поведение [United Nations 1987; Lloyd, Ivanov 1988]. Стохастическое моделирование позволяет показать, как изменения в смертности порождают климат, необходимый для снижения рождаемости. Таблица 2 показывает результаты модели, в которой удвоение продолжительности жизни радикально меняет распределения доживающих до 20-летнего возраста. В ней сопоставляются распределения семей, в которых родилось по шесть детей, по числу доживших до 20-летнего возраста при режиме высокой смертности (продолжительность жизни при рождении 25 лет) и при режиме средней смертности (продолжительность жизни 50 лет).

Таблица 2. Средние распределения женщин, родивших шестерых детей, по числу детей, доживших до 20-летнего возраста, в условиях высокой и средней смертности, $\%$

\begin{tabular}{c|c|c}
\hline $\begin{array}{l}\text { Число детей, доживших до } \\
20 \text { лет }\end{array}$ & $\begin{array}{c}\text { Продолжительность жизни при } \\
\text { рождении } 25 \text { лет }\end{array}$ & $\begin{array}{c}\text { Продолжительность жизни при } \\
\text { рождении } 50 \text { лет }\end{array}$ \\
\hline 0 & 3 & 0 \\
1 & 13 & 0 \\
2 & 27 & 3 \\
3 & 30 & 11 \\
4 & 19 & 28 \\
5 & 7 & 37 \\
6 & 1 & 21 \\
Всего & 100 & 100 \\
\hline
\end{tabular}

Примечание: Основано на «западной» совокупности модельных таблиц смертности и допущении, что вероятность смерти не зависит от порядка рождения.

Источник: [McNicoll 1986].

В режиме высокой смертности распределение доживающих непредсказуемо. Почти три четверти (73\%) матерей потеряют не меньше половины рожденных ими шестерых детей. Следовательно, при таком уровне рождаемости и смертности трехдетность недостижима для большинства семей. У значительной доли (16\%) женщин, родивших шестерых детей, до 20 лет доживет не более одного ребенка; только 1\% женщин не испытает потери ребенка. В таких условиях необходимо родить много больше шести детей, чтобы с достаточной вероятностью иметь четверых или более доживших до 20-летнего возраста детей. Однако допереходные уровни смертности и заболеваемости делали это недостижимым для многих женщин. Более того, такие условия в принципе неблагоприятны для формулирования количественных репродуктивных целей. Всемирное обследование 
рождаемости 1970-х годов подтвердило, что в странах с особенно высокой смертностью значительная доля женщин не в состоянии ответить на вопрос о желаемом числе детей [United Nations 1987].

Положение решительно меняется, когда продолжительность жизни удваивается. Только одна седьмая часть (14\%) женщин потеряют как минимум половину своих детей, в то время как более одной пятой $(21 \%)$ не испытают потери ребенка. Цель вырастить до зрелости не менее четырех детей становится реальной для абсолютного большинства семей, в том числе для 86\% женщин, родивших шестерых детей. Иными словами, значительное снижение младенческой и детской смертности создает демографическую среду, в которой связь между числом рождений и числом выживших детей становится достаточно предсказуемой для формулирования на индивидуальном уровне репродуктивных целей, что, в свою очередь является предпосылкой снижения рождаемости путем планирования семьи.

Национальные медико-демографические обследования DHS, начатые в конце 1980х годов и продолжающиеся поныне, показывают, что в большинстве развивающихся стран доля бездетных женщин, не давших количественного ответа на вопрос о желаемом числе детей, резко снизилась. Хотя снижение произошло не везде и новый демографический климат представляет собой не единственную причину количественного оформления репродуктивных установок, в данных таблицы 3 проявляются тенденции к осознанию возможности управлять своим поведением, которая в свою очередь обусловлена интернализацией новых объективных - значительно более благоприятных и предвидимых - вероятностей выживания детей.

Таблица 3. Доля бездетных женщин, не давших количественного ответа на вопрос о желаемом числе детей

\begin{tabular}{|c|c|c|c|}
\hline \multirow[b]{2}{*}{ Страна } & \multicolumn{2}{|c|}{ Доля не давших ответа, \% } & \multirow[b]{2}{*}{$\begin{array}{c}\text { Снижение смертности детей до } 5 \text { лет } \\
\text { между обследованиями, \% }\end{array}$} \\
\hline & $\begin{array}{c}\text { конец 1980-х - } \\
\text { начало 1990-х годов }\end{array}$ & 2000-е годы & \\
\hline Бангладеш & 14 & 3 & 34 \\
\hline Гана & 13 & 2 & 28 \\
\hline Иордания & 34 & 6 & 31 \\
\hline Малави & 11 & 3 & 19 \\
\hline Мозамбик & 22 & 1 & 24 \\
\hline Марокко & 25 & 2 & 26 \\
\hline Танзания & 15 & 3 & 21 \\
\hline Эритрея & 11 & 6 & 32 \\
\hline
\end{tabular}

Источник: Demographic and Health Surveys (URL: http://dhsprogram.com/data/).

Роль снижения детской смертности в снижении рождаемости тем отчетливее, чем больше роль родителей в обеспечении здоровья детей. Это - не тривиальное утверждение, а следствие дуализма выживаемости детей: она зависит как от внешних, неподконтрольных родителям условий, так и от их действий или бездействия. В этом контексте нуждаются в корректировке представления о том, что инфекционные заболевания - т.е. неподконтрольные родителям причины смерти - доминировали в допереходный период.

Основными причинами смерти в течение первых 20 лет жизни являются «некоторые младенческие болезни» и поносы; респираторные заболевания, включая грипп, пневмонию 
и бронхиты; «другие инфекционные и паразитарные» заболевания и респираторный туберкулез. Эти три группы причин смерти охватывали $3 / 4$ младенческих и детских смертей в допереходных и раннепереходных странах. В большинстве развивающихся стран эпидемические инфекционные и паразитарные заболевания (кроме малярии) играли небольшую роль в структуре причин смерти младенцев, детей и подростков, в которой преобладали младенческие заболевания, поносы и респираторные заболевания [Galway et al. 1987]. От половины до трех четвертей снижения смертности в 1950-1970-х годах было обусловлено уменьшением числа смертей от респираторных заболеваний, туберкулеза и малярии [Preston 1980], т.е. тех болезней, в лечении и профилактике которых родители играют активную роль. Таким образом, во многих развивающихся странах преобладала именно такая структура снижения младенческой, детской и подростковой смертности, которая предполагает активную роль родителей и потому благоприятствует укоренению идеи планирования семьи. Эта структура детской смертности типична не для всех развивающихся регионов: вероятно (хотя этому есть лишь спорадические эмпирические подтверждения), в Африке к югу от Сахары смертность снижалась главным образом за счет инфекционных заболеваний, профилактика которых требует меньшего участия семьи; в результате уровень детской смертности в регионе выше, чем в других, а планирование семьи распространено меньше.

Другие характеристики режима смертности также влияют на зарождение планируемого родительства. Чем более риск смерти сконцентрирован в узком интервале времени после рождения ребенка, тем более предсказуемой становится связь между деторождением и размером семьи. И наоборот, чем дольше ребенок подвергнут значительному риску смерти, тем менее предсказуемой оказывается эта связь и тем менее привлекательным и эффективным будет планирование семьи. Демографический переход как раз и характеризуется такой прогрессирующей концентрацией.

Снижение детской смертности повышает предсказуемость семейного строительства: родители начинают ощущать возможность управлять прокреацией, вследствие чего идея планирования семьи обретает смысл. Это фундаментальное изменение и делает снижение детской смертности триггером перестройки репродуктивного поведения. Появляются осознанные стратегии, увязывающие репродуктивное поведение с ожидаемой (страховое поведение) и реальной (замещающее поведение) смертностью детей. Осуществление этих стратегий предполагает регулирование числа и графика рождений.

В условиях регулируемого деторождения (планируемого родительства) семьи могут достигать желаемого числа детей, приспосабливаясь к уровню детской смертности одним из двух способов: страховой стратегией или стратегией замещения [United Nations 1987; Lloyd, Ivanov 1988]. Страховая стратегия представляет собой репродуктивное поведение, нацеленное на достижение желаемого числа детей большим числом рождений, исходя из возможности смерти ребенка (или детей), в том числе и в отдаленном будущем, за пределами репродуктивного периода, когда уже нельзя будет компенсировать смерть ребенка рождением другого. Чем больше воспринимаемый родителями риск потерять одного или нескольких детей, тем больше превышение желаемого числа рождений над желаемым числом детей. Поскольку в условиях высокой смертности велика неопределенность выживания, значительное число родителей теряют больше детей, чем 
предполагается средним уровнем смертности. Поскольку никто из родителей не может знать наперед истинную вероятность смерти своих детей, подавляющее большинство будет вести себя так, как если бы они были в группе повышенного риска. В результате многие родители завершат репродуктивный период с большим числом выживших детей, чем они планировали.

Стратегия замещения означает, что в семье происходят дополнительные рождения взамен умерших детей. Это достигается сокращением интергенетических интервалов, рождением дополнительного ребенка (детей) в конце репродуктивного периода или комбинацией этих двух способов. Чем больше запланированные родителями интергенетические интервалы, тем проще осуществлять замещающую стратегию. В противном случае замещение должно происходить, когда плодовитость женщины падает. Возможность эффективного замещения зависит от наличия обратимых методов контрацепции.

Действие этих двух стратегий различно. Стратегия замещения предполагает приспособление к случившейся потере, в то время как страховая стратегия предполагает, что родители планируют свое поведение на основе некоторого представления об уровне детской смертности. Реализованную стратегию замещения нельзя изменить, в то время как родители, выбравшие страховую стратегию, могут изменить ее на стратегию замещения, если окажется, что выживаемость уже рожденных детей выше, чем они предполагали. Может быть и так, что родители совмещают обе стратегии, страхуясь наперед только от тех детских смертей, которые могут случиться за пределами репродуктивного периода.

Моделирование демографических последствий реализации страховой стратегии в различных социально-экономических условиях и режимах смертности показывает, что в развивающихся странах, в особенности в Юго-восточной Азии, вклад этой стратегии в снижение рождаемости был достаточен для существенного снижения неттокоэффициентов воспроизводства поколений [United Nations 1987].

Эмпирическое измерение замещающего поведения предполагает сравнение числа детей, рожденных после ребенка некоторой очередности, в зависимости от того, испытала или нет женщина потерю ребенка меньшей очередности. Результаты исследований по Иордании, Колумбии, Коста-Рике, Мексике, Марокко, Непалу, Пакистану, Перу, Тайваню и Шри Ланке показывают, что на каждые 100 предотвращенных смертей приходится от 30 до 60 несостоявшихся рождений [Lloyd, Ivanov 1988], что согласуется с коэффициентом макроуровневой корреляции дожития и числа рожденных детей $(0,6)$. Исследование по Республике Корея обнаружило, что замещающий эффект был ничтожен в поколениях, родившихся до 1955 г., а в поколениях 1965-1971 гг. рождения достиг 50\%, что связано с распространением практики планирования семьи [Park et al. 1979].

Страховое поведение измерялось реже. Для этого использовался корреляционный анализ связи реального или желаемого числа детей с субъективным представлением родителей о вероятности выживания детей или некоторым объективным показателем условий смертности. Применение этой техники к данным по Тайваню показало, что представление о более высокой вероятности выживания своих детей, равно как и проживание в населенном пункте с меньшей смертностью, связаны с существенно более 
низкой рождаемостью [Heer, Wu 1975]. Исследование по Египту [Rizk et al. 1980] дало схожий результат.

\section{РОЛЬ НЕДЕМОГРАФИЧЕСКИХ ФАКТОРОВ В СНИЖЕНИИ РОЖДАЕМОСТИ}

Снижение детской смертности является необходимым и главным фактором перестройки репродуктивного поведения, характеризующегося низкой рождаемостью. Иными словами, если из 1000 рожденных 300-350 детей умирают, не достигнув пятилетнего возраста, рождаемость вряд ли сдвинется с уровня, превышающего 6-7 детей на женщину. Однако это не означает, что снижение рождаемости повсюду и обязательно следует курсом, параллельным снижению детской смертности. В современном мире экстремально высокая рождаемость (более 6 детей на женщину) при низкой детской смертности сохраняется в иудейских общинах харедим (Израиль, США) и протестантских общинах меннонитов и амишей (США, Канада). Более того, глобальному демографическому переходу свойственны лаги между началом снижения смертности и началом снижения рождаемости, а затем - вариации углов наклона траекторий дальнейшего снижения смертности и рождаемости. Вероятно, продолжительность этих лагов и величина расхождений трендов детской смертности и рождаемости определяются социокультурными и экономическими факторами, в том числе институциональными, определяющими особенности семейной организации. Конечно, с высоты общей теории демографического перехода эта вариабельность может выглядеть излишней подробностью, а обусловливающие ее факторы - ненужными для понимания демографического воспроизводства. Но речь идет о миллиардных различиях в численности мирового населения (и колоссальных различиях в его географическом распределении), которые накапливаются вследствие вариаций параметров демографического перехода.

Разумно предположить (что и делает большинство исследователей), что существуют и недемографические факторы, систематически влияющие на репродуктивное поведение и параметры демографического перехода. Как и во всех других типах и формах поведения, среди этих факторов присутствуют экономические, социальные и культурные феномены. И эти факторы действительно оказывают большое, а в некоторых обществах определяющее влияние на репродуктивное поведение.

Так, повышение спроса на детей вследствие того, что средняя цена выжившего ребенка снизилась, может быть значительным в некоторых условиях. Такие условия типичны для аграрных обществ, где сильны семейные связи (затраты на ребенка распределены среди родственников), дети являются важным трудовым ресурсом, земля относительно обильна или велики возможности миграций. Такие условия типичны для некоторых регионов Юга, в особенности для Африки к югу от Сахары. Снижение средней цены выживающего ребенка обычно сопровождается улучшением здоровья детей и, следовательно, их экономической ценности для родителей, что может также повысить желаемое число детей. В таких условиях снижение детской смертности может и не привести к снижению рождаемости. 
Число рождений зависит не только от достижимости того или иного желаемого числа детей, но и самой репродуктивной цели. Радикальное улучшение выживаемости детей способствует формулированию индивидуальных репродуктивных целей. Желаемое число (выживших) детей было бы единой для всех константой, если бы деторождение в каждой семье выполняло единственную (популяционную) функцию - например, обеспечивать воспроизводство стационарного населения. В действительности желаемое число детей зависит от множества социокультурных факторов. В отношении этой характеристики популяции неоднородны, причем и все основные модернизационные процессы ограничивают потребность в детях. Например, эта потребность снижается, когда модернизация меняет тип и структуру занятости. В частности, расширение рынка женского труда в несельскохозяйственных сферах экономики создает представление об утерянном доходе вследствие деторождения. Образование с одной стороны улучшает контроль над выживаемостью детей, т.е. повышает их «предложение», а с другой - увеличивает прямые затраты на детей, уменьшает использование детского труда и обостряет конфликт между количеством и качеством детей. Эти частные процессы сливаются в общий фундаментальный сдвиг, меняющий соотношение межпоколенных потоков благ в семье: в традиционном обществе чистый поток благ направлен от детей к родителям, а в современных обществах - от родителей к детям [Caldwell 1980; 1982; 2001].

Действительность, конечно, сложнее этого схематичного описания. Подчас развивающиеся страны характеризуются разными факторами детерминации экономической потребности семей в детях, которые по-разному отвечают на импульсы модернизации. В Латинской Америке, где еще сравнительно недавно большинство крестьян арендовали маленькие наделы (минифундио) у крупных землевладельцев (латифундистов) в обмен на труд, причем в значительной степени детский, механизация крупного сельского хозяйства снизила экономическую полезность детей. Во многих районах Тропической Африки общинное землевладение и переложное земледелие в прошлом были основаны на изобилии земли, что позволяло родителям увеличивать обрабатываемые наделы за счет детского труда, не снижая производительность и не вызывая парцелляцию земли. В 1950-1970-е годы эрозия почвы, обезлесение и опустынивание уменьшили емкость экосистем и подорвали общинное землевладение, в результате чего снизилась экономическая полезность детей в сельском хозяйстве. Однако это не обязательно снижает полезность детского труда вообще. Так, в некоторых наименее развитых странах Азии и Африки обезлесение и нарастающий дефицит пресной воды вызвали увеличение потребности в детском труде, ибо женщины перестали справляться с обеспечением хозяйства топливом и водой. Более того, там, где большие вложения труда являются единственным способом компенсировать нехватку земли, экономическая полезность детей высока. Поэтому, хотя генеральной тенденцией является сокращение использования детского труда, в сельской местности наименее развитых стран нарастающий дефицит природных факторов производства отчасти компенсируется растущей вовлеченностью детей в жизнеобеспечение семьи, что задерживает демографический переход.

При этом, как правило, использование детского труда сокращается параллельно со снижением рождаемости (таблица 4). Однако эта связь не очень тесна, потому что в 
некоторых странах действуют противоположные факторы: в последние десятилетия в ряде развивающихся стран очень ухудшилась доступность питьевой воды и хвороста, в результате чего возросла ценность детей как добытчиков этих жизненно необходимым ресурсов.

Таблица 4. Коэффициенты экономической активности детей в возрасте до 15 лет (КЭА) и суммарные коэффициенты рождаемости (СКР) в некоторых развивающихся странах в периоды до 1985 г. и после 1995 г.

\begin{tabular}{|c|c|c|c|c|c|c|}
\hline \multirow{2}{*}{ Страна } & \multicolumn{3}{|c|}{ Первый период } & \multicolumn{3}{|c|}{ Последний период } \\
\hline & Год & КЭА & CKP & Год & КЭА & CKP \\
\hline \multicolumn{7}{|c|}{ Азия } \\
\hline Индонезия & 1961 & 23 & 5,7 & 1997 & 9 & 2,6 \\
\hline Пакистан & 1972 & 40 & 6,6 & 2015 & 17 & 4,3 \\
\hline Шри Ланка & 1953 & 11 & 5,9 & 2010 & 1 & 2,2 \\
\hline \multicolumn{7}{|c|}{ Африка } \\
\hline Мадагаскар & 1975 & 44 & 7,2 & 2010 & 20 & 4,7 \\
\hline Судан & 1983 & 39 & 6,6 & 1996 & 15 & 5,8 \\
\hline \multicolumn{7}{|c|}{ Латинская Америка } \\
\hline Бразилия & 1980 & 20 & 4,1 & 2014 & 8 & 1,8 \\
\hline Колумбия & 1951 & 17 & 6,8 & 2010 & 8 & 2,0 \\
\hline Мексика & 1960 & 22 & 6,8 & 2004 & 10 & 2,6 \\
\hline
\end{tabular}

Примечание: Доля работающих и безработных (т.е. экономически активных) рассчитана на основе переписей населения и обследований занятости с использованием определения Международной организачии труда (MOT), которое включает в число занятых неоплачиваемых семейных работников, если они работают не менее одной трети нормального рабочего времени.

Источники: По коэффициенту экономической активности - базы данных Международной Организации Труда Laborsta (http://laborsta.ilo.org/) и Ilosta (http://ilostat.ilo.org); по суммарному коэффиииенту рождаемости - [United Nations 2017: FERT/4].

Расширение охвата школьным обучением и рост образовательного уровня оказывают понижающее воздействие как на детскую смертность, так и на потребность в детях. Однако образование снижает рождаемость лишь в той мере, в какой оно модернизирует поведение женщин и увеличивает альтернативную стоимость их рабочего времени. Сам по себе рост образовательного уровня не обязательно ведет к модернизации поведения. В странах Африки и Азии социализация через школу, особенно начальную, может закреплять традиционные гендерные отношения, в том числе раннее вступление в брак и его всеобщность, а также ориентацию на многодетность [Caldwell 1980]. Такие воздействия могут встречаться в аграрной сельской среде, но в городах они распространены меньше.

Существует немало исторических доказательств того, что жесткое применение законов об обязательном школьном образовании и обучение на государственном языке с использованием общенациональных программ сыграли ключевую роль в сокращении демографического разнообразия, преобладавшего в Европе в середине XIX века и во время демографического перехода [Watkins 1991]. В развивающихся странах роль единых национальных образовательных систем как трансляторов норм современного репродуктивного поведения не меньше. Обзор литературы по Африке [Lloyd et al. 2000] подтвердил действие этого механизма в регионе. Исследование в Непале и Пакистане 
показало, что само наличие в общине школы меняет репродуктивное поведение даже тех ее членов, кто не получил формального образования [Montgomery et al. 2000].

Если воздействие начального образования на репродуктивное поведение может в некоторых условиях быть неоднозначным, то получение женщиной (да и мужчиной) среднего и высшего образования несомненно является сильным предиктором меньшего итогового числа детей. Тому есть две причины, которые взаимосвязаны так сильно, что их трудно эмпирически разделить. Во-первых, образовательный контент среднего и высшего образования и атмосфера соответствующих учебных заведений хорошо способствуют интернализации современных стереотипов. Во-вторых, образование сверх начального дает возможность найти работу в современном секторе экономики и таким образом продолжить интеграцию в современный образ жизни. Эта интеграция включает конфликт между временем, затрачиваемым для ухода за детьми, и оплачиваемым трудом (утраченный доход). К этому добавляется конфликт между перерывами в занятости, связанными с деторождением и уходом за младенцем, и стремлением сохранить работу и делать карьеру. Эти цепочки связей зарождаются и крепнут прежде всего (а в самых бедных странах исключительно) в среднем классе, но формируемое ими поведение нередко распространяется и на низшие городские страты: диффузия осуществляется через имитацию поведения, сопутствующего жизненному успеху.

В другом ракурсе взаимосвязь между образованием и демографическими событиями концептуализируется как рост значения качества детей, что требует больших инвестиций в их воспитание и образование и, следовательно, при ограниченных ресурсах заставляет родителей «жертвовать» количеством детей [Montgomery et al. 2000]. Этот эффект усиливается от поколения к поколению, поскольку более образованные родители более склонны вкладывать в человеческий капитал своих детей.

Несмотря на отмеченную выше неоднозначность воздействия формальных знаний и школьной социализации на репродуктивное поведение, статистическая связь соответствующих переменных весьма сильна. Так, коэффициент корреляции между средней продолжительностью обучения и рождаемостью (рисунок 2$)^{11}$ составляет $-0,78$ для 76 стран в 2000-2016 гг. ${ }^{12}$ Обширный обзор исследований на данных многих развивающихся стран подтвердил связь между достигнутым уровнем образования (особенно женщин) и последующими демографическими событиями, включая возраст при вступлении в первый брак и число рождений [Jejeebhoy 1995].

11 Большая методологическая чистота при использовании итоговых чисел детей у женщин и их образовательного уровня в реальных когортах достижима ценой отодвигания объекта анализа на несколько десятилетий назад. Здесь «актуализация» достигнута путем использования условно-когортных показателей и ценой уязвимости обвинению в смешении яблок с апельсинами, потому что сопоставляются данные по неидентичным совокупностям. Однако сопоставления в данном случае все же оправданы тем, что яблоки и апельсины эволюционируют сравнительно медленно, а разброс их характеристик по странам велик. Средняя продолжительность обучения 25-летних женщин, не являясь непосредственной характеристикой совокупности женщин детородного возраста, все же удовлетворительно аппроксимирует их образовательный уровень.

12 Для каждой страны выбран год последнего наблюдения продолжительности обучения. 
В странах, проходящих ранний этап демографического перехода, очень неравномерное распределение населения по образовательному уровню определяет и глубокую дифференциацию репродуктивного поведения. Вместе с тем в это время в населении абсолютно преобладают люди, не имеющие никакого образования или имеющие лишь начальное. Так, в сельских местностях Нигерии в настоящее время 54\% женщин репродуктивного возраста не имеют никакого образования (в городах 16\%), в то время как доля женщин с образованием выше среднего составляет всего 4\% (17\%). Из числа необразованных замужних матерей и женатых отцов в возрасте 15-49 лет с четырьмя живыми детьми не хотят дальнейшего расширения семьи лишь $10 \%$ и $2 \%$ соответственно. В группе лиц с начальным образованием доля желающих ограничиться имеющимися четырьмя детьми составляет уже $31 \%$ среди женщин и $22 \%$ среди мужчин, а в группе имеющих образование выше среднего - соответственно 60 и 42\%. Этим предпочтениям соответствует и демографический результат: суммарный коэффициент рождаемости необразованных женщин составляет 6,9 ребенка на женщину, в то время как женщин с образованием выше среднего - 3,1 ребенка на женщину. Конечно, и детская смертность тоже является функцией образовательного уровня родителей: в группе необразованных матерей она составляет 180 промилле против 128 промилле в группе женщин с начальным образованием и 62 промилле у женщин с образованием выше среднего [National Population ... 2014], что может быть интерпретировано как воздействие образования (и связанного с ним благосостояния) на рождаемость через детскую смертность. Однако перестройка репродуктивного поведения в зависимости от образования идет быстрее, чем падение детской смертности; это согласуется с предположением о том, что образование имеет и прямое (помимо смертности) понижающее воздействие на рождаемость ${ }^{13}$.

Вместе с тем уровень образования, как бы его ни измерять и каким бы ни была его роль в формировании репродуктивного поведения, сам по себе - недостаточный предиктор рождаемости. Вариации других факторов (детской смертности в той мере, в какой она не зависит от поведения родителей, экономических укладов, образа жизни, контрацептивного поведения) в широких пределах усиливают или ослабляют воздействие образования. Так, при одинаковом среднем числе лет обучения женщин (4 года) суммарная рождаемость в Индии составляет 2,6 ребенка, а в Уганде - 6 детей на женщину.

Процессом наиболее высокого порядка, всегда способствующим модернизации как репродуктивного, так и любого другого поведения, является урбанизация. Город всегда был фокусом модернизации, а подчас ее монопольной средой. Жизнь в городе обусловливает меньшую детскую смертность, потому что в городах, как правило, лучше доступ к чистой воде, бытовому электричеству, гигиеническим знаниям, образованию, рынку труда, более высоким и растущим доходам, средствам массовой информации. Развитие этих компонентов городского образа жизни способствует перестройке репродуктивного поведения горожан, а перераспределение населения из сельской местности в города

\footnotetext{
${ }^{13}$ База данных национальных обследований DHS (URL: http://dhsprogram.com/data/), в том числе проведенных в Нигерии, позволяет проводить проверки гипотез о связи многочисленных социально-экономических индикаторов с репродуктивным поведением. Проведенные автором расчеты по 10 странам (Бангладеш, Египет, Индонезия, Колумбия, Мали, Мексика, Нигерия, Тунис, Филиппины, Шри Ланка) показывают, что из всех этих индикаторов образование наиболее тесно связано с итоговым числом детей.
} 
ускоряет демографический переход в национальном масштабе. Кроме того, развитие городов оказывает модернизационное влияние на окружающую их сельскую местность.

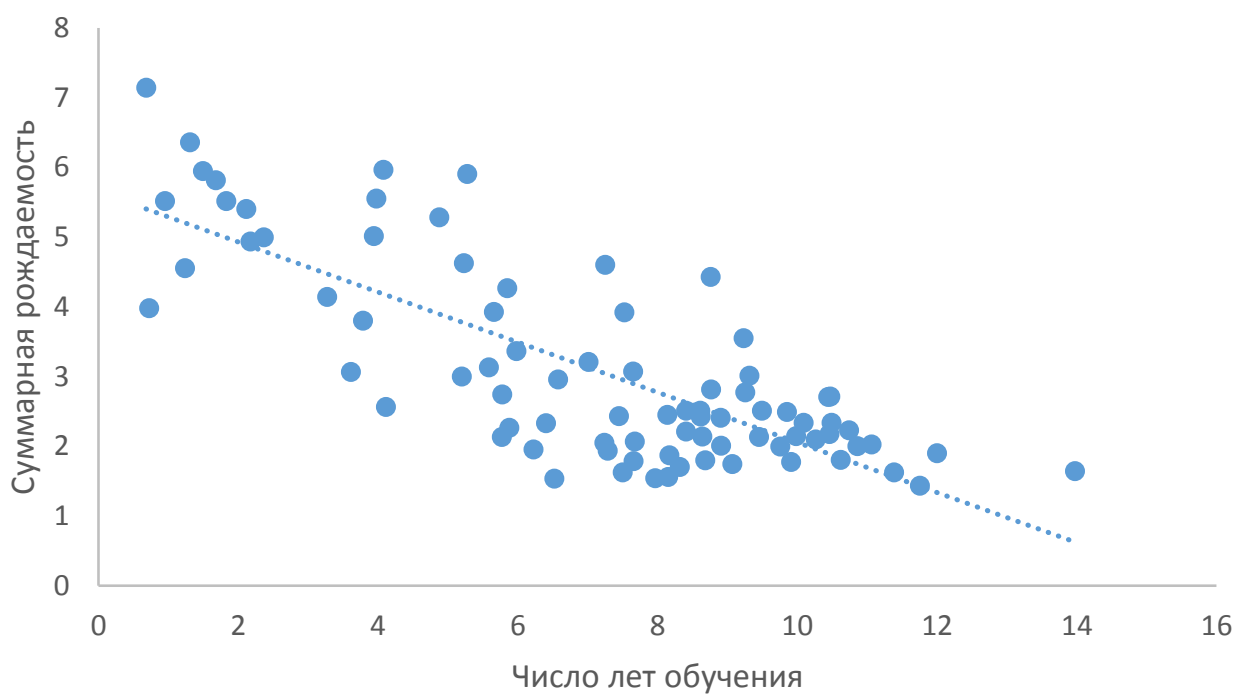

Рисунок 2. Среднее число лет обучения женщин 25-летнего возраста и старше и коэффициент суммарной рождаемости в 76 развивающихся странах в 2000-2016 гг.

Примечание: Оценки среднего числа лет обучения получены из обследований или государственной отчетности. Использованные здесь оценки наиболее свежие (по состоянию на 20.05.2017) из включенных в статистическую базу Юнеско. Годы, на которые приводятся оценки среднего числа лет обучения, и годы, на которые приводятся суммарные коэффициенты рождаемости, идентичны.

Источник: Базы данных Юнеско (URL: data.uis.unesco) u [United Nations 2017: FERT/4].

Вместе с тем корреляция рождаемости с урбанизацией часто существенно слабее, чем можно предположить, исходя из представления о том, что оба процесса являются модернизационными изменениями высшего порядка. Отчасти дело в разнородности национальных дефиниций городских поселений. В одних странах любое поселение с числом жителей более 500-1000 считается городом, в других порог людности не только в десятки раз выше, но и дополняется плотностью застройки (или населения) или структурой занятости. Такие различия мешают не только международным сопоставлениям, но и анализу хронологических рядов по тем странам, в которых в силу тех или иных причин используются неадекватные статистические критерии. Но есть и сущностные факторы, ослабляющие статистическую связь. Масштабы урбанизации многих стран Юга очень велики, но перестройка репродуктивного поведения еще масштабнее прежде всего потому, что там, где рождаемость снижается, она снижается не только в городах, но и в сельской местности, хотя и медленнее. Кроме того, урбанизация не сводится к перераспределению населения, а включает изменения образа жизни: оба процесса не идентичны, но однонаправлены, а их соотношение различается от страны к стране. В частности, разные типы урбанизации по-разному меняют репродуктивное поведение. Так, развитие более или менее плавно иерархизированной сети городов сопровождается обычно более быстрым снижением рождаемости, чем концентрация городского населения в мегаполисах с большой долей трущоб, как, например, в Нигерии, Мали и Пакистане. Но вместе с тем причиной более быстрого демографического перехода в одних странах по сравнению с 
другими является модернизация репродуктивного поведения сельского большинства, что в свою очередь является функцией снижения детской смертности и расширения использования контрацепции в консервативной среде. Такой прогресс достижим, только если государство развивает здравоохранение и обеспечивает универсальный доступ к программам планирования семьи.

\section{АнТинАтАЛИзм14}

В 1970-1980-е годы рост населения развивающихся стран настолько ускорился, а его негативные последствия [Horlacher et al. 1986; Иванов 1982; 2010; 2013; 2015] становились настолько очевидны, что все больше и больше развивающихся стран официально вставали на путь антинатализма. Глобальное распространение эксплицитной демографической политики стало результатом длительного взаимодействия трех сил: самих развивающихся стран, Соединенных Штатов Америки и Организации Объединённых Наций [Иванов 2011; 2017].

В 1960-1970-е годы демографический взрыв стал одной из самых идеологизированных тем во взаимоотношениях Юга с Западом. Лозунги о коварном империалистическом вмешательстве во внутренние дела развивающихся стран, подмене задач борьбы с неоколониализмом программой подавления демографического взрыва обусловливались господствовавшим состоянием умов раннего постколониального периода. С начала 1970-х годов Движение неприсоединения (а затем и Группа 77) объединили свои силы с коммунистическими государствами в борьбе с «мальтузианскими» утверждениями о негативном характере последствий быстрого роста населения. Нередко инвективы по другим сюжетам подкреплялись «антимальтузианством», так как считалось, что оно содержит бесспорные, неубиваемые аргументы. Даже Индия, с начала 1950-х годов проводившая политику сдерживания роста населения в стране, на международной арене проявляла солидарность с антимальтузианством Группы 77. Европейские правительства избегали полемики, не желая антагонизировать развивающиеся страны по вопросу, который они считали одновременно маргинальным и не поддающимся решению.

Однако прагматическая идея ускорения демографического перехода в целях улучшения перспектив национального развития пробивала себе дорогу, постепенно преодолевая или игнорируя идеологические шоры. Число государств, вставших на антинаталистскую платформу, уже к середине 1970-х годов достигло 76 (таблица 5). Более того, некоторые государства де-факто начали осуществлять антинаталистскую политику, сохраняя официальную удовлетворенность темпом роста населения и заявляя о своем невмешательстве в репродуктивное поведение, либо осуществляя демографическую политику под рубрикой улучшения репродуктивного здоровья. Однако несмотря на крен в

14 В научной литературе и политическом дискурсе «антинатализм» обычно заменяется громоздкими эвфемизмами типа «стремление воздействовать на динамику населения» или «политика снижения рождаемости». По нашему мнению, термины «антинатализм» и «пронатализм» адекватно и четко отражают суть соответствующих позиций. 
сторону программ репродуктивного здоровья ${ }^{15}$, непоследовательное сочетание громких антимальтузианских лозунгов или нейтралистских политических деклараций (с тем же антимальтузианским подтекстом) с прагматической антинаталистской политикой теряет популярность: число стран, не проводящих официальную демографическую политику, снизилась с 78 до 13.

Таблица 5. Распределение развивающихся стран по направлениям официально заявленной политики в отношении рождаемости, 1976-2015

\begin{tabular}{|c|c|c|c|c|c|}
\hline & 1976 & 1986 & 1996 & 2005 & 2015 \\
\hline \multicolumn{6}{|c|}{ Антинаталистская } \\
\hline Африка & 12 & 21 & 35 & 36 & 45 \\
\hline Азия & 14 & 15 & 18 & 16 & 18 \\
\hline Латинская Америка & 10 & 13 & 16 & 16 & 10 \\
\hline \multicolumn{6}{|c|}{ Невмешательство } \\
\hline Африка & 38 & 27 & 14 & 13 & 3 \\
\hline Азия & 22 & 21 & 13 & 8 & 2 \\
\hline Латинская Америка & 18 & 17 & 13 & 9 & 8 \\
\hline \multicolumn{6}{|c|}{ Пронаталистская } \\
\hline Африка & 4 & 6 & 5 & 5 & 6 \\
\hline Азия & 10 & 10 & 15 & 22 & 26 \\
\hline Латинская Америка & 2 & 0 & 1 & 5 & 12 \\
\hline
\end{tabular}

Источник: [United Nations 2015].

При этом эрозия в прошлом преобладавшей группы «нейтралов» идет в двух направлениях: в сторону не только распространения антинатализма, но и экспансии пронатализма в Азии и Латинской Америке, где число государств, стоящих на этой позиции, выросло с 16 до 44. Рост пронатализма является следствием не разочарованности в результатах политики антинатализма, а напротив, еe успехов: в этих странах демографический переход завершился во многом благодаря успешной антинаталистской политике, но рождаемость «проскочила» порог простого воспроизводства или оказалась от него в неприемлемой близости. Таково положение, например, в Венесуэле, Вьетнаме, Китае, Иране, Малайзии, Республике Корея, Сальвадоре, Шри Ланке, ряде островных государств Карибского бассейна. Эволюция других латиноамериканских стран была иной. Демографический переход в Аргентине, Боливии, на Кубе, в Чили сопровождался позицией невмешательства государств, а когда рождаемость приблизилась к уровню простого воспроизводства или оказалась ниже его, эти государства склонились к пронатализму. Обычно пронаталистски настроенные страны (как развивающиеся, так и развитые) не могут похвастаться внятными достижениями в области демографической динамики. Убедительно купировать или развернуть тренд снижения рождаемости не удается: за период 1976-2015 гг. суммарный коэффициент в условиях пронатализма сократился, как и в «нейтральных» странах, на 1,9 ребенка на женщину (таблица 6). Официальное провозглашение цели снижения рождаемости означает, как правило, проведение последовательной и активной

15 Отсутствие международных стандартов классификации деятельности в этой области препятствует выяснению вопроса, отражает ли опережающий рост ассигнований на репродуктивное здоровье реализацию новых приоритетов в ущерб демографической политике или это статистический артефакт, обусловленный переквалификацией отдельных сопрограмм и проектов. 
политики по ее достижению. В странах, преследовавших цель снижения рождаемости, коэффициент суммарной рождаемости снизился в среднем за 1976-2015 гг. на 3,1 ребенка на женщину, т.е. на $60 \%$ больше, чем в странах-нейтралах и пронаталистах.

Во всей этой динамике большую роль играли позиция и политика Соединенных Штатов Америки в силу как их ведущей роли в политических взаимоотношениях Запада и Юга, так и веса в официальной помощи развитию. США стали адептом и проводником внутренне непротиворечивого и практически ориентированного подхода, в соответствии с которым быстрый рост населения тормозит экономическое развитие и дестабилизирует развивающиеся страны. Можно, конечно, просто приклеить к этому подходу ярлык неомальтузианства, но это само по себе его не отрицает, ибо существующая критика логически ущербна и практически деструктивна. К выработке этого подхода вел длинный и тернистый путь.

Таблица 6. Снижение суммарных коэффициентов рождаемости в десятилетних интервалах в зависимости от позиции 127 развивающихся государств в отношении рождаемости, 1976-2015 гг., невзвешенные средние

\begin{tabular}{l|c|c|c|c|c}
\hline & $1976-1986$ & $1986-1996$ & $1996-2005$ & $2005-2015$ & $1976-2015$ \\
\hline Антинаталистская & 0,9 & 1,0 & 0,7 & 0,5 & 3,1 \\
Невмешательство & 0,5 & 0,7 & 0,5 & 0,2 & 1,9 \\
Пронаталистская & 0,4 & 0,8 & 0,5 & 0,2 & 1,9 \\
\hline
\end{tabular}

Источник: [United Nations 2015: FERT/4].

К концу 1950-х годов в научных кругах США победило мнение, что быстрый рост населения имеет больше негативных, чем позитивных последствий, снижение рождаемости является функцией социального прогресса, но процесс можно ускорить, проводя антинаталистскую политику, стержнем которой является обеспечение широкого доступа к эффективной контрацепции. Потребовалось полтора десятилетия, чтобы государство преодолело опасения, что политическая поддержка, финансовая и техническая помощь такой демографической политике будут восприняты в странах Юга как расовый империализм. Преодолению этих опасений способствовала как аналитическая работа различных правительственных органов (госдепартамента, Пентагона, Агентства международного развития, разведывательного сообщества), доклады комитетов и комиссий Конгресса и правительства ${ }^{16}$, так и уже начавшаяся деятельность американских частных фондов и неправительственных организаций.

Это экспертное сообщество апеллировало не только к возможности торможения демографического взрыва в развивающихся странах, но и к его полезности для национальной безопасности и геополитических интересов США. Логика состояла в том, что быстрый рост населения, высокая доля молодежи, интенсивные внутренние миграции и растущее стремление эмигрировать тормозят экономический рост и подрывают

\footnotetext{
16 Доклад Президентского комитета по военному сотрудничеству (1959 г.), доклад Комитета по усилению безопасности свободного мира (1963 г.), доклад ЦРУ о потенциальных последствиях мировых тенденций в населении, климате и производстве продовольствия (1974 г.), важнейший доклад Национального совета безопасности о последствиях роста мирового населения для безопасности и зарубежных интересов Соединенных Штатов (1974 г.) [United States National... 1974].
} 
политическую стабильность в странах, в чьем развитии заинтересованы Соединенные Штаты. Демографическое давление особенно опасно в крупных странах-производителях минерального сырья, а также в государствах-стратегических союзниках, под которыми имелись в виду Бангладеш, Бразилия, Египет, Индия, Индонезия, Колумбия, Мексика, Нигерия, Пакистан, Таиланд, Турция, Эфиопия и Филиппины. В то время эти страны обеспечивали половину глобального прироста населения. В более широком смысле быстрый рост населения создает угрозу глобальным экономическим, политическим и экологическим системам. Большое влияние на руководство страны оказал первый доклад Римскому клубу [Meadows et al. 1972; Meadows et al. 2004], в котором системнодинамический подход обнаруживает важнейшую роль демографического роста как разрушительной силы в мировом масштабе. Колебания были преодолены к Всемирной Конференции ООН по народонаселению (Бухарест 1974).

Достижение международного консенсуса по проблематике народонаселения развивающихся страны было очень желательным. Накал идеологических разногласий, хотя и не предотвращал, но серьезно затруднял не только международное сотрудничество в этой области, но и выработку глобальных стратегий социально-экономического развития. Вероятно, национальные программы и международное сотрудничество развивались бы и без общей платформы, объединяющей всех участников, поскольку и Запад, и Юг были заинтересованы в практическом решении проблем народонаселения Юга. Но универсальное, хотя бы рамочное, соглашение было нужно.

Начиная с середины 1960-х годов Организация Объединенных Наций стала наиболее авторитетной платформой обсуждения социально-экономических проблем демографической динамики развивающихся стран, содержания и детерминации демографического перехода. Организованные ООН глобальные межправительственные конференции по народонаселению $\left(1974,1984\right.$ и 1994 г. $\left.^{17}\right)$ и полтора десятка региональных форумов позволили ввести эту проблематику в контекст мирового развития, прийти к существенным консенсусным формулировкам и легитимизовать антинаталистский подход и программы планирования семьи. Хотя в ретроспективе такая парадигма кажется естественной, а язык планов и программ действий, принятых на этих конференциях бледным и неконкретным, без них демографическая проблематика долго оставалась бы вне мейнстрима девелопментализма, а важнейшие аспекты вмешательства в воспроизводство населения пребывали бы табуированными сюжетами. Пока консенсус «не дорос» до эксплицитного признания отрицательного баланса последствий быстрого роста населения в развивающихся странах. Однако принятые планы и программы действий, дискуссии на заседаниях, обмен мнениями на полях конференций подтачивали антимальтузианские стереотипы и способствовали продвижению в правительства развивающихся стран антинаталистских идей.

Одновременно развивалась практическая деятельность организации, в центре которой находится созданный в 1968 г. Фонд ООН по народонаселению (ЮНФПА) с мандатом оказывать развивающимся странам содействие в разработке и реализации

\footnotetext{
${ }^{17}$ А также Конференция по правам человека (Тегеран 1968).
} 
демографической политики с упором на программы планирования семьи. В этой и сопредельных областях работают также Всемирная организация здравоохранения, Детский фонд ООН, Фонд ООН по СПИДу (UN-AIDS), OOH-Женщины (UN-Women). Помощь ООН национальным программам демографической политики имела двоякое значение. ЮНФПА оказывал решающее техническое и финансовое содействие на первых этапах разработки и функционирования программ планирования семьи, стал крупнейшим донором, канализирующим более половины глобальных потоков международных ресурсов помощи этим программам. Менее явное, но не менее важное значение имела пропаганда, особенно среди правительств, еще не выбравших подход к демографическим проблемам к середине 1970-х годов.

\section{ПЛАНИРОВАНИЕ СЕМЬИ}

Регулирование деторождения, которое позволяет добиться желаемого числа детей и интервалов между рождениями, а также, в некоторых случаях, заданной гендерной структуры потомства - составляет суть планируемого родительства (внутрисемейного планирования рождаемости). Образование, занятость, урбанизация формируют потребность в детях, детская смертность формирует сознательное целеполагание и определяет разницу между этой потребностью и числом рождений, необходимых для ее удовлетворения. Люди реализуют свои репродуктивные стратегии посредством современной и традиционной контрацепции, абортов или абстиненции. В развивающихся странах, за исключением Китая, СНГ и еще нескольких стран, законодательство жестко ограничивает условия, при соблюдении которых государство разрешает аборты. В частности, почти повсеместно аборты не разрешаются на основании экономических причин и, тем более, по простому требованию женщины.

Современная контрацепция дает возможность эффективно и дешево осуществлять репродуктивные планы. Однако не следует забывать, что современная контрацепция не является единственно возможным инструментом снижения рождаемости. В странах Севера контрацептивная революция [Вишневский и др. 2017] скорее последовала за демографическим переходом, чем сделала его возможным. Вместе с тем в контексте демографической динамики глобального Юга контрацептивная революция произошла как нельзя более кстати, когда демографический взрыв был в полном разгаре. Контрацептивная революция 1960-1970-х годов породила набор высокоэффективных противозачаточных средств и методов и тем способствовала широкому распространению контрацептивного поведения, по существу неизвестного ранее. Не случись этой революции, снижение детской смертности могло бы затормозиться, а то и захлебнуться: увеличивающийся разрыв между реальным числом рождений и желаемым числом детей вылился бы в большую избирательность поведения в отношении детей различных очередностей, а также в рост использования традиционных неэффективных мер предупреждения беременности. Наряду с этим растущий дисбаланс между желаемым и действительным числом детей привел бы к еще большему ускорению демографического роста. До 1960-х годов регулирование деторождения, т.е. разведение сексуальной практики и рождаемости, если и осуществлялось, то с помощью презервативов (единственного в ту пору эффективного, но 
для абсолютного большинства жителей развивающихся стран недоступного средства) и малоэффективными так называемыми традиционными способами, среди которых преобладали сексуальное воздержание (в том числе «календарный» метод) и coitus interruptus. Существовавшие тогда международные различия в использовании контрацепции были обусловлены в основном неодинаковой популярностью презервативов, в частности их большей распространенностью в Латинской Америке. В настоящее время в большинстве стран из практикующих контрацепцию 90\% используют эффективные современные средства: противозачаточные таблетки, внутриматочные устройства (ВМУ), инъекции и стерилизацию, а также презервативы. Культурные особенности обусловливают различные предпочтения методов контрацепции. Так, в Северной Африке используются в основном противозачаточные таблетки, в Турции, Сингапуре и странах Южной Африки презервативы, во Вьетнаме и Иордании - ВМУ, в Китае - стерилизация и ВМУ, в Индонезии и Кении - инъекции.

Использование контрацепции зависит от спроса и предложения медикаментов, приспособлений и процедур. Помимо фундаментальных факторов, о которых речь шла выше, спрос формируется осведомленностью о контрацептивных технологиях и их культурной приемлемостью. Контрацептивные средства должны быть доступны как по цене, так и по территориальной близости к их источникам. В развивающихся странах вообще и в их сельских поселениях в особенности располагаемые доходы и возможности рыночных механизмов в распространении современной контрацепции намного уступают развитым странам. Без целенаправленного вмешательства на макроуровне контрацептивная революция в странах Юга не состоялась бы. Это целенаправленное вмешательство было обеспечено национальными программами планирования семьи.

Программы планирования семьи обычно являются общегосударственными, но осуществляются пунктами медицинского обслуживания низшего звена или представляют собой сеть автономных центров и специализированных отделений в общих больницах. Программа предоставляет контрацептивные услуги и информирует население по всем связанным с контрацепцией вопросам, включая планируемое родительство, а также по проблематике народонаселения и устойчивого развития. Контрацептивные услуги включают индивидуальные консультации с целью осведомить клиентов об особенностях разных контрацептивных средств и методов временного и постоянного действия, их возможных побочных эффектах и альтернативах; стерилизации, имплантации и инъекции; периодическое предоставление противозачаточных средств разового действия. Программы планирования семьи создаются государствами в сотрудничестве с НПО, обычно национальными членами Международной ассоциации планируемого родительства. Услуги предоставляются по сильно субсидируемым ценам или бесплатно. Большую, а часто решающую роль в распространении планируемого родительства играет официальная помощь развитию, предоставляемая по линии ЮНФПА или по каналам двусторонней помощи. В 1970-1980-х годах активную роль играл частный американский Фонд Форда, после Каирской Конференции 1994 г. крупным донором стал американский частный фонд Билла и Мелинды Гейтс.

В рамках Всемирной программы действий в области народонаселения (1994 г.), Декларации тысячелетия ООН и Повестки дня ООН в области устойчивого развития на 
период до 2030 г. приоритетное внимание стало уделяться репродуктивному и сексуальному здоровью, а планирование семьи часто переформулируется как репродуктивные права. Это ведет, в частности, к интегрированию предоставления контрацептивных услуг в более масштабную деятельность. Интеграция позволяет объединить усилия персонала, преодолевая дефицит кадров и обеспечивая комплексное оказание медицинских услуг. Во многих случаях услуги оказываются в одном здании, одним медицинским учреждением и, как правило, одними и теми же сотрудниками этого учреждения. Вместе с тем интеграция может препятствовать концептуализации сокращения рождаемости в контексте развития, а также затрудняет оценку ресурсного обеспечения этой цели. Общенациональные инстанции планирования семьи (обычно правительственные комиссии среднего иерархического уровня, редко - со статусом министерства) часто компенсируют эти тенденции, поддерживая антинаталистский характер программ планирования семьи.

Как правило, объектом программы планирования семьи является все население страны, в том числе сельское и бедное городское. В некоторых странах развитие сети центров планирования семьи начиналось не из столицы, а из сельских районов с самой высокой рождаемостью. Программы планирования семьи не только способствуют удовлетворению спроса на контрацепцию, но и помогают людям осознать нужность и осуществимость ограничения рождаемости, т.е. трансформируют латентный спрос в эффективный. Эта функция особенно важна в отсталых сельских районах, где единственным альтернативным каналом получения информации о современной контрацепции и образцом для подражания в новом типе репродуктивного поведения оказываются родственники и соседи, обратившиеся в новые центры планирования семьи. Еще одним важным принципом планирования семьи является добровольность участия в программе. Серьезные, но преодоленные, нарушения этого принципа на некоторых этапах развития демографической политики в Индии и Китае получили широкую известность, которая заслонила тот факт, что практически во всех остальных развивающихся странах никогда не было нареканий по этому вопросу.

Контрацепция стоит недорого, а ее гуманитарная ценность и экономическая эффективность высоки [Bongaarts, Siding 2009]. Так, предотвращение нежелательного рождения значительно дешевле, чем санитарная профилактика диареи или краткий курс химиотерапии при туберкулезе. Модернизация технологий и инфляция резко (в 7 раз в период 1995-2015 гг.) повысили среднюю цену контрацепции, но в абсолютном выражении она остается скромной. Однако не менее 330 млн людей ею не пользуются, потому что ни они сами, ни программы планирования семьи не обладают достаточными ресурсами. Годовые совокупные затраты на планирование семьи в развивающихся странах составляют, по примерной оценке, 12,4 млрд долл. Из этой суммы 8,5 млрд долл. представляют собой выплаты из семейных бюджетов, 3 млрд - внутренние ресурсы развивающихся государств и 0,9 млрд - международная двусторонняя и многосторонняя помощь (из 162 млрд долл. чистой официальной помощи развитию, предоставленной странами ОЭСР в 2014 г.). Большая часть ресурсов, поступающих из внутренних источников, приходится на несколько крупных стран. Многие страны, особенно страны Африки к югу от Сахары и наименее развитые страны, не в состоянии мобилизовать достаточные ресурсы для 
финансирования своих программ и в большой степени зависят от донорской помощи. В 1960-1970-е годы абсолютное большинство программ (за ярким исключением Китая) не могло бы организовать эффективные программы без иностранной помощи. Полное удовлетворение потребностей в современных противозачаточных средствах обойдется в 9,4 млрд долл., не включая личные средства пользователей [Singh et al. 2014].

Планирование семьи обладает синергетическим эффектом, облегчая выполнение задач в области репродуктивного здоровья. Каждый доллар, израсходованный на противозачаточные средства, снижает стоимость ухода, связанного с беременностью, на полтора доллара. В развивающихся странах ежегодные 70-80 млн нежелательных беременностей приводят к 140-150 тыс. смертей женщин и 1,4 млн младенческих смертей в год, многие из которых программы планирования семьи могут предотвратить. В случае увеличения финансирования на 850 млн долл. в год программа поставок ЮНФПА могла бы предотвратить в 2016-2020 гг. 116 млн случаев нежелательной беременности и 2,2 млн случаев материнской и младенческой смертности [UNFPA 2014].

\section{Таблица 7. Распределения стран по уровням и среднегодовым темпам прироста охвата контрацепцией в 1960-2010-х годах}

\begin{tabular}{l|c|c|c|c|c|c|c}
\hline & \multicolumn{2}{|c|}{ Темп прироста, п.п. в год } & \multicolumn{3}{c}{ Охват контрацепцией (2010-е годы), \% } \\
\cline { 2 - 8 } & $\begin{array}{c}\text { Азия и } \\
\text { Северная } \\
\text { Африка }\end{array}$ & $\begin{array}{c}\text { Латинская } \\
\text { Америка }\end{array}$ & $\begin{array}{c}\text { Африка к } \\
\text { югу от } \\
\text { Сахары }\end{array}$ & $\begin{array}{c}\text { Азия и } \\
\text { Северная } \\
\text { Африка }\end{array}$ & $\begin{array}{c}\text { Латинская } \\
\text { Америка }\end{array}$ & $\begin{array}{c}\text { Африка к } \\
\text { югу от } \\
\text { Сахары }\end{array}$ & $\begin{array}{c}\text { Развитые } \\
\text { страны }\end{array}$ \\
\hline Минимум & 0,0 & 0,0 & 0,0 & 18,8 & 2,0 & 1,7 & 7,0 \\
1 -й квартиль & 0,6 & 0,4 & 0,4 & 34,6 & 48,5 & 11,5 & 44,4 \\
Медиана & 0,9 & 0,8 & 0,8 & 45,5 & 57,9 & 25,0 & 53,5 \\
Средняя & 0,8 & 0,9 & 0,6 & 46,8 & 64,0 & 18,5 & 61,4 \\
3-й квартиль & 1,3 & 1,2 & 1,2 & 57,0 & 71,8 & 33,5 & 70,1 \\
Максимум & 2,9 & 1,8 & 2,2 & 84,0 & 78,2 & 66,5 & 84,0 \\
Число стран & 41 & 25 & 45 & 47 & 28 & 47 & 33 \\
\hline
\end{tabular}

Примечания: Охват контрацепџией оценивается как доля женщчин (как правило, в возрасте 15-49 лет), состоящих в браке или незарегистрированном союзе и использующчи современные методы контрацепции (или их партнеры используют контрацеепцию), в общей численности таких женщин.

Темп прироста рассчитан как разница коэффициентов использования контрацепции на дату последнего и первого обследований, деленная на разность дат этих обследований. Этот подход оправдан, так как в абсолютном большинстве стран динамика использования контрацепции линейна. Обследования проведены в периоды 1968-1981 и 2000-2014 г2.

Источник: [United Nations 2016].

Начиная со второй половины 1960-х годов в азиатских и латиноамериканских странах стало быстро расширяться использование современных контрацептивных средств. Это не значит, что повсеместно охват современной контрацепцией начал расти одновременно или одинаково быстро, но полностью он стагнировал лишь в нескольких странах, в то время как в половине стран использование контрацепции увеличивалось не менее, чем на 0,8-0,9 п.П. в год, а в четверти стран быстрее, чем на 1,2 п.п. в год. К 2010-м годам латиноамериканский регион обогнал развитые страны по некоторым характеристикам распределения стран по уровню охвата современной контрацепцией (таблица 7). В большинстве стран Азии и Латинской Америки (разброс национальных 
уровней показан в таб. 8) в целом завершен по меньшей мере первый этап распространения современной контрацепции (когда охват превышает 50\%): там применяют контрацепцию соответственно 64 и 72\% состоящих в браке или незарегистрированном союзе женщин детородного возраста; по развитым регионам в целом этот показатель составляет 70\%.

\section{Таблица 8. Уровень использования контрацепции и уровень рождаемости в некоторых развивающихся странах в 1960-1970-х и 2010-х годах}

\begin{tabular}{|c|c|c|c|c|c|c|c|c|}
\hline \multirow[t]{2}{*}{ Страна ${ }^{\mathrm{a}}$} & \multicolumn{2}{|c|}{$\begin{array}{c}\text { Годы } \\
\text { обследований }\end{array}$} & \multicolumn{2}{|c|}{$\begin{array}{c}\text { Охват } \\
\text { контрацепцией }^{b}\end{array}$} & \multirow{2}{*}{$\begin{array}{c}\text { Степень } \\
\text { удовлетворения } \\
\text { потребности }^{\mathrm{c}} \\
\text { (2) }\end{array}$} & \multicolumn{2}{|c|}{$\begin{array}{c}\text { Суммарный } \\
\text { коэффициент } \\
\text { рождаемости }\end{array}$} & \multirow{2}{*}{$\begin{array}{c}\begin{array}{l}\text { Теснота } \\
\text { связи }^{\mathrm{d}}\end{array} \\
(2)\end{array}$} \\
\hline & $(1)$ & (2) & (1) & (2) & & (1) & (2) & \\
\hline \multicolumn{9}{|c|}{ Азия } \\
\hline Индия & 1970 & 2007 & 10 & 48 & 64 & 5,6 & 2,8 & $-0,96$ \\
\hline Индонезия & 1973 & 2015 & 7 & 59 & $\ldots$ & 5,3 & 2,4 & $-0,98$ \\
\hline Турция & 1963 & 2013 & 7 & 47 & 60 & 6,1 & 2,1 & $-0,99$ \\
\hline Китай & 1982 & 2006 & 67 & 85 & 97 & 2,5 & 1,5 & $-0,90$ \\
\hline Таиланд & 1969 & 2012 & 15 & 77 & 89 & 5,8 & 1,5 & $-0,99$ \\
\hline \multicolumn{9}{|c|}{ Латинская Америка } \\
\hline Гаити & 1977 & 2012 & 5 & 32 & 45 & 5,8 & 3,2 & $-0,99$ \\
\hline Парагвай & 1977 & 2008 & 23 & 71 & 84 & 5,2 & 2,9 & $-0,99$ \\
\hline Эквадор & 1979 & 2012 & 26 & 72 & 81 & 4,9 & 2,6 & $-0,97$ \\
\hline Мексика & 1976 & 2014 & 23 & 68 & $82^{e}$ & 5,9 & 2,4 & $-0,99$ \\
\hline Колумбия & 1969 & 2009 & 9 & 73 & 84 & 5,8 & 2,0 & $-1,00$ \\
\hline \multicolumn{9}{|c|}{ Африка } \\
\hline Мали & 1987 & 2012 & 5 & 10 & 27 & 7,2 & 6,4 & $-0,94$ \\
\hline Нигерия & 1981 & 2013 & 1 & 10 & $29^{f}$ & 6,8 & 5,7 & $-0,84$ \\
\hline Сенегал & 1978 & 2015 & 1 & 21 & 46 & 7,5 & 5,0 & $-0,88$ \\
\hline Судан & 1978 & 2014 & 4 & 12 & 30 & 6,9 & 4,4 & $-0,92$ \\
\hline Кения & 1977 & 2015 & 4 & 60 & 75 & 7,7 & 4,3 & $-0,95$ \\
\hline
\end{tabular}

Примечания: (1) - первое обследование; (2) - последнее обследование.

а - Страны отобраны таким образом, чтобы представлять большой, для соответствуюших регионов, разброс охвата контрацепцией в годы обследований, проведенных позднее 2005 г.

b - Охват контрацепцией оценивается как доля женщин (как правило, 15-49 лет), состоящих в браке или незарегистрированном союзе и использующих контрацепцию, в общей численности таких женщин.

c - Степень удовлетворения потребности в современной контрацепции оценивается как доля женщин (как правило, 15-49 лет), состоящих в браке или незарегистрированном союзе и используюших контращепџию, в общей численности женщин, состоящих в браке или незарегистрированном союзе и желающих использовать контрацепциию (в \%).

d - Коэффициент линейной корреляции между динамикой охвата контрацепцией и динамикой суммарного коэффищиента рождаемости, по странам (6-25 наблюдений по стране).

$e-20092$

$f-20112$.

Источник: [United Nations 2016].

Вместе с тем в обоих регионах есть отстающие страны. Если в Китае применяют современную контрацепцию 84\% женщин (уровень так же высок только в Великобритании), то в Афганистане, Ираке, Йемене, Камбодже и Пакистане уровень применения контрацепции ниже $30 \%$. В Латинской Америке и Карибском бассейне уровень применения противозачаточных средств варьируется от $30 \%$ на Гаити до 75\% в Бразилии и на Кубе. Африка отстала в использовании современной контрацепции: на континенте ей охвачено лишь 20\% замужних женщин детородного возраста, причем контрацепция используется на континенте особенно неравномерно. Контрацептивная революция 
началась там на 2-3 десятилетия позднее, чем в Азии, и далеко продвинулась лишь в Северной и Южной Африке, где от половины до двух третей женщин применяют контрацепцию, а в четверти стран к югу от Сахары охват не превышает 10\%. В некоторых южноафриканских странах борьба с эпидемией ВИЧ/СПИДа привела к росту использования презервативов, что дало не только профилактический, но и контрацептивный эффект. В Восточной, Западной и Центральной Африке контрацепция распространяется намного медленнее, уровень ее использования во многих странах остается очень низким, а темпы роста намного меньше, чем в Азии и Латинской Америке. Динамика использования контрацепции в Африке говорит о том, что на континенте в целом она не соответствует требованиям модернизации репродуктивного поведения. Трудно определить, в какой мере это результат сохраняющихся массовых установок на многодетность, обусловленных высокой младенческой и детской смертностью, традиционностью рынка труда, низким образовательным уровнем и низким уровнем урбанизации, а в какой - неразвитостью и бедностью национальных программ планирования семьи, однако ясно, что все эти факторы релевантны.

Там, где распространенность контрацепции растет, рождаемость снижается. Существование этой зависимости оспаривалось, но возражения исчерпывающе опровергли Бонгаартс и Синдинг [Bongaarts, Sinding 2009]. Таблица 8 показывает исключительно тесную корреляцию между хронологическими рядами охвата контрацепцией и суммарной рождаемостью в 15 различных по демографическим условиям странах Азии, Латинской Америки и Африки. Кроме того, коэффициенты корреляции превышают 0,90 в 59 странах, не приведенных в таблице 8, для которых существуют временные ряды с более чем 5 наблюдениями. В поперечном срезе последних оценок использования контрацепции по 77 развивающимся странам коэффициент их корреляции с суммарной рождаемостью (в те же годы) составляет $0,87$.

\section{ДЕМОГРАФИЧЕСКИЙ ПЕРЕХОД НА ГЛОБАЛЬНОМ ЮГЕ: ПРОМЕЖУТОЧНЫЕ ИТОГИ}

За полвека в воспроизводстве населения большинства развивающихся стран произошли тектонические сдвиги: многократно снизилась детская смертность, радикально изменилось репродуктивное поведение, отгремел и затихает демографический взрыв. Главной нынешней характеристикой мирового населения является разнообразие этапов демографического перехода и, соответственно, темпов роста населения. В развитых странах он завершился несколько десятилетий назад, численность населения «золотого миллиарда» почти стабилизировалась на уровне 1,3 млрд человек при среднегодовом естественном приросте в 1 млн человек, а через 5 лет начнет убывать. Китай прошел демографический переход позже, но намного быстрее, почти сравнялся по численности населения с глобальным Севером. Поскольку рождаемость в Китае значительно ниже уровня простого воспроизводства населения, затухающий рост населения через 3-10 лет сменится устойчивым сокращением и по среднему варианту демографического прогноза ООН к концу века население страны уменьшится на 400 млн человек или на 30\% от максимальной численности. В другом демографическом гиганте - Индии - рождаемость пока значительно 
выше, в результате чего население в течение полувека будет расти, пока не достигнет 1,7 млрд человек (на 1/3 больше, чем в Китае).

Многие другие развивающиеся страны Азии и Латинской Африки уже прошли весь демографический переход. Когда выработается демографический потенциал, их ожидает либо нулевой, либо умеренно-отрицательный рост населения, а там, где снижение рождаемости было особенно быстрым и глубоким, развернется депопуляция. Все больше развивающихся стран «не останавливаясь» переходят Рубикон простого замещения поколений: в 2005 г. их было 28, а в 2015 г. - уже 43. В азиатских, латиноамериканских и североафриканских странах, находящихся в промежуточных фазах демографического перехода, динамика населения будет, вероятно, по форме схожей, но сдвинутой во времени на несколько десятилетий.

Таким образом, рост совокупного населения этих регионов (не включая Китай и Индию), проходящих (за исключением нескольких азиатских наименее развитых стран) или завершивших демографический переход, продолжится еще полвека. Если сейчас в этих странах проживают 2,5 млрд человек (в 1950 г. было 0,6 млрд), то к 2070 г. совокупная численность их населения достигнет 3,4 млрд человек, а затем несколько (на 100 млн человек) снизится к концу века (рисунок 3 ).

Демографический переход, являясь важнейшим компонентом модернизации, в целом благоприятствует социальному развитию и экономическому росту. Между тем его конкретные последствия зависят от конкретной социально-экономической среды. Так, в «азиатских тиграх» глубокая и масштабная перестройка репродуктивного поведения началась до старта бурного экономического роста. Сам по себе демографический переход вряд ли был триггером экономического чуда, но быстрое замедление роста населения способствовало прогрессу, в особенности накоплению человеческого капитала. В частности, замедление темпов роста контингентов школьного возраста, их стабилизация, а тем более сокращение способствует росту охвата обучением и повышению удельных капиталовложений. Преходящее значительное увеличение доли образованной молодежи в населении в сочетании с благоприятным рынком труда стало фактором экономического роста, получившим название «демографический дивиденд». Между тем положительное действие такого возрастного сдвига не гарантировано - оно обусловлено социальноэкономической моделью, в том числе устройством государства и его политикой. В ряде стран Западной Азии и Северной Африки как раз быстрый рост численности и увеличение удельного веса молодежи, в особенности ее образованной части, при высоком уровне безработицы и блокированной вертикальной мобильности питали социальную напряженность и способствовали смене политических режимов в ходе Арабской весны, что, правда, пока не привело к разрешению противоречия, поскольку экономические проблемы не только не были решены, но даже усугубились.

В глобальном масштабе завершению демографического перехода препятствует Африка к югу от Сахары. Африка из относительно малонаселенного континента превратилась в демографического гиганта, количественно сравнимого с «золотым миллиардом». Большинство стран региона находятся лишь в начальной стадии демографического перехода, а в некоторых снижение рождаемости с очень высоких 
уровней еще не началось. В настоящее время средний уровень рождаемости в регионе чуть меньше 5 детей на женщину, но в 19 странах из 50 суммарный коэффициент превышает 5, в том числе в 7 странах он больше 6 детей на женщину. Высокая рождаемость уже обусловила опережающий рост населения региона, которое в период с 1950 г. увеличилось со 180 млн до миллиарда человек. По среднему варианту прогноза ООН суммарная рождаемость в регионе снизится к середине столетия до 3,1 ребенка на женщину, а к концу - до 2,2. Такая траектория соответствует более медленному падению рождаемости, чем это имело место в прошлом в других развивающихся регионах, но все же предполагает завершение демографического перехода в интервале 85-90 лет. Однако огромный потенциал роста, заложенный в очень молодой структуре населения (что в свою очередь является результатом длительного сохранения высокой рождаемости при снижающейся смертности), предопределяет гигантский прирост населения, которое к концу столетия по среднему варианту прогноза ООН достигнет почти 4 млрд человек (таково было население всего мира в 1974 г.). Нынешняя роль Африки к югу от Сахары в мировой демографической динамике намного усилится. Если сейчас этот регион обеспечивает 1/3 прироста мирового населения, то к концу века он будет перекрывать депопуляцию остального мира и обеспечивать прирост мирового населения на 13-16 млн человек в год.

Даже у «антимальтузианцев» и «пролайферов» такая перспектива должна вызывать опасения. Понятно, что если рождаемость будет по-прежнему сокращаться медленно, бремя быстрого роста населения будет по-прежнему тормозить экономический рост. При типичной для Африки неразвитости факторов производства и запутанности социокультурных ограничений трудно надеяться на экономический бум масштабов, достаточных для многократного увеличения емкости среды обитания. И это - линейная экстраполяция, в то время как вполне возможны перерывы постепенности - локальные кризисы и многоуровневые катастрофы. Это превращает ускорение демографического перехода в приоритет.

В центре демографической проблемы Африки к югу от Сахары находится Нигерия - крупнейшая страна региона (рисунок 4). При мало изменившейся рождаемости и сократившейся смертности ее население выросло с 38 млн человек в 1950 г. до 192 млн в 2017 г. В соответствии со средним вариантом прогноза ООН, исходящим из предположения, что рождаемость будет постепенно сокращаться такими же темпами, которые в среднем были свойственны развивающимся странам на сходных этапах демографического перехода, суммарный коэффициент снизится с нынешних 5,7 детей на женщину до 3,6 в середине столетия и 2,3 в его конце. По такому сценарию к середине XXI века Нигерия по численности населения сравняется с США, а к концу столетия в стране будет больше 750 млн жителей, что эквивалентно 60\% общего числа жителей развитых стран. Маловероятно, что даже поддержание достигнутого в последнее время динамичного экономического роста окажется достаточным для обеспечения жизнедеятельности такого количества людей.

Низкий вариант прогноза по Нигерии, в соответствии с которым суммарная рождаемость будет снижаться ненамного быстрее и к концу века окажется на уровне 1,8 детей на женщину, приводит к численности населения в 2100 г. в 540 млн человек, что наполовину меньше, чем в среднем варианте прогноза, но все же почти на 90 млн человек 
больше, чем ожидаемое население США. Таким образом, узкая вилка суммарных коэффициентов рождаемости в конце прогнозного периода (0,5 детей на женщину) обусловливает 210-милионную разницу в численности населения. Это является следствием длительного сохранения высокой рождаемости, создавшей огромный демографический потенциал.

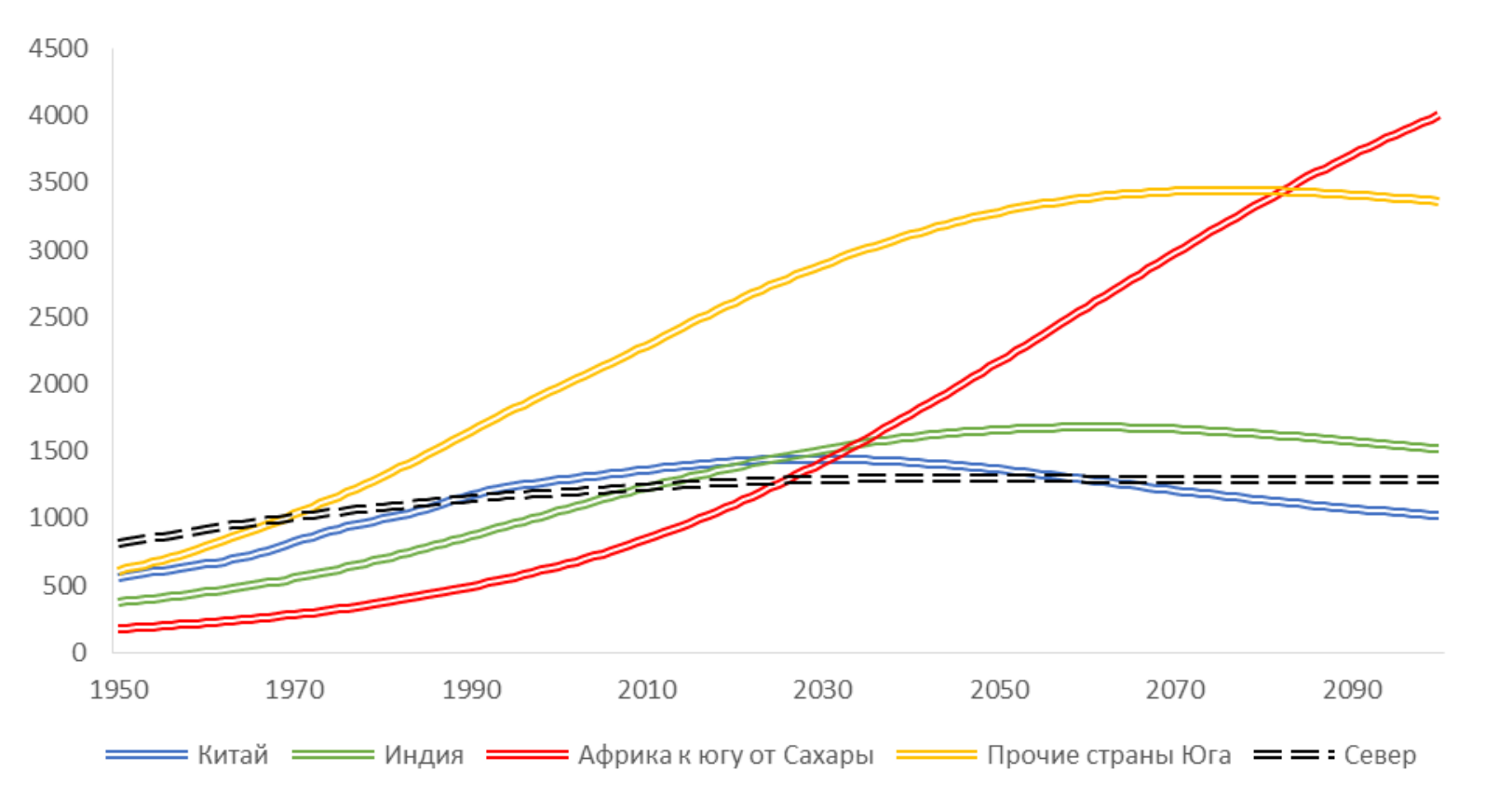

Рисунок 3. Численность населения некоторых стран и регионов в 1950-2015 гг. (оценка) и 2016-2100 гг. по среднему варианту прогноза ООН, млн человек

Источник: [United Nations 2017].

Если же предположить, что рождаемость сохранится на нынешнем уровне, то население страны экспоненциально возрастет до почти 3 млрд человек. Такой сценарий может показаться не имеющей отношения к действительности иллюстрацией общеизвестных демографических формул. Однако было бы заблуждением уповать на адаптационные механизмы, которые как-нибудь разрешат проблему, своевременно обрушив рождаемость. Приходится признать, что вполне вероятно появление разнообразных мальтузианских ловушек невиданных масштабов.

Демографическая проблема в Нигерии и соседних странах объективно существует и в будущем непременно обострится. Страна не может позволить себе пренебрежение своим демографическим будущим. Не обязательно ждать до конца столетия, чтобы быстрый рост населения самой крупной африканской страны породил хронический дефицит доступного продовольствия, потоки беженцев и вынужденных переселенцев, болезненную урбанизацию, пандемии смертоносных болезней, безработицу большинства трудоспособного населения, дополнительную нагрузку на госбюджет и сокращение возможностей человеческого и инфраструктурного развития, Понятно, что такие последствия не могут не подорвать экономическую и политическую стабильность страны, остановить, а то и повернуть вспять, ее развитие. Более того, демографическое будущее 
Нигерии станет серьезным вызовом международной безопасности, если не удастся решительно ускорить демографический переход.

Можно не соглашаться с «демографическим детерминизмом», утверждая, что эти несчастья обусловлены политэкономическими и политическими причинами и дефицитом ресурсов вследствие колониального ограбления и неоколониальной эксплуатации. Но было бы странно отрицать, что быстрый рост населения в условиях отсталости является линзой, усиливающей практически все проблемы. Быстрый рост населения способствует относительному перенаселению, которое проявляется в распространении трущоб, растущем давлении на миграционный клапан, расшатывающих государство массовых волнениях и росте его агрессивности. Внутреннее давление может спонтанно и неуправляемо открыть клапан эмиграции, увеличив ее объем на порядок по сравнению с нынешним уровнем; куда и в какой форме направятся эти потоки, приходится только гадать. Может оказаться, что сопоставимые объёмы иммиграции понадобятся постпереходным странам, чтобы компенсировать демографически обусловленное сокращение национальных трудовых ресурсов [Ivanov 2010]. Чтобы механизм сообщающихся сосудов не создал больше проблем, чем разрешит, нужна взаимная адаптация мигрантов и принимающих обществ, но практика показывает, что это часто не получается и с нынешними потоками эмиграции с Юга на Север.

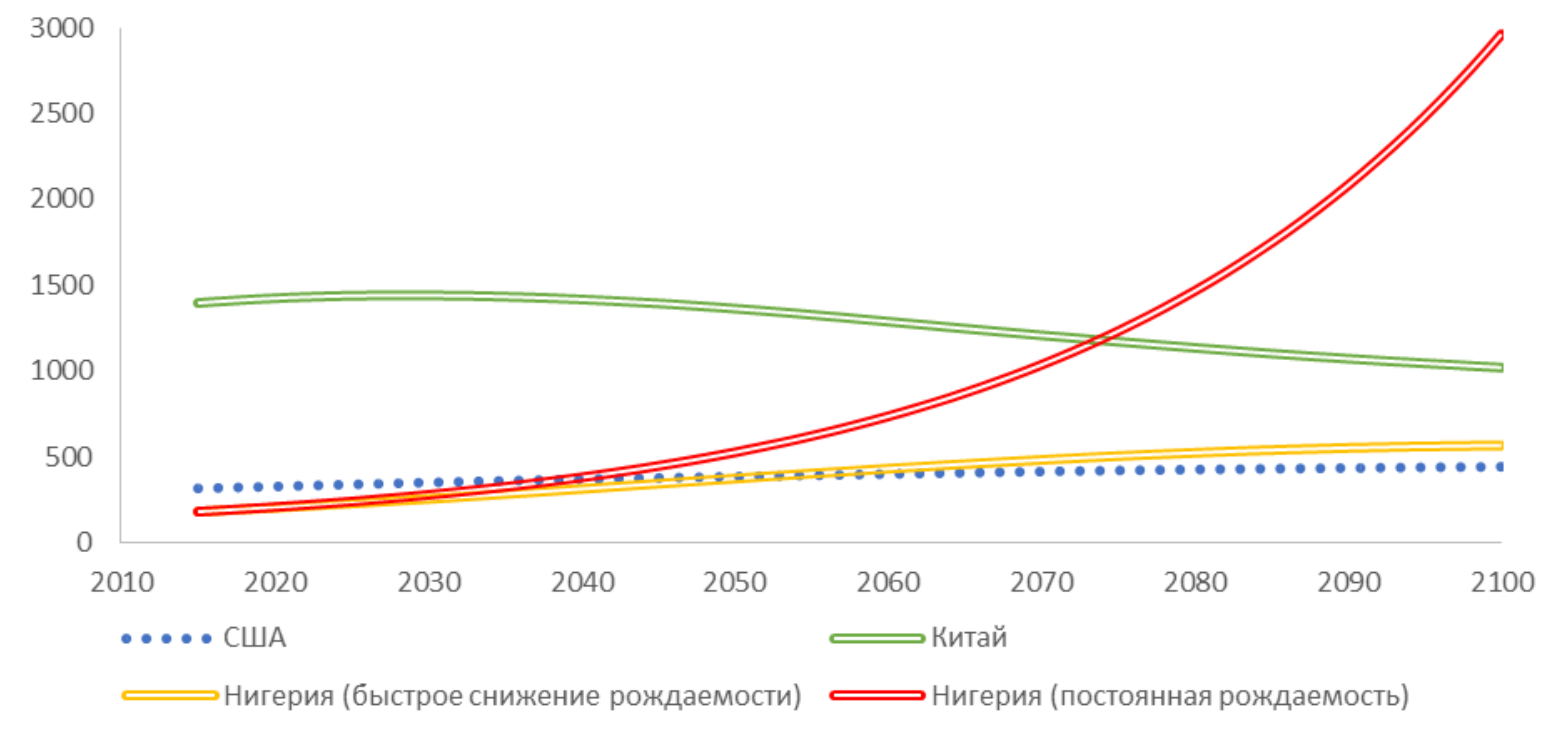

Рисунок 4. Прогноз численности населения США (средний вариант), Китая (средний вариант) и Нигерии (сценарий быстрого снижения рождаемости ${ }^{18}$ и сценарий постоянной рождаемости $\left.{ }^{19}\right)$, 2016-2100 гг., млн человек

Источник: [United Nations 2017: Pop/1-1].

Возможно ли радикально ускорить демографический переход? Исторический опыт дает утвердительный ответ на этот вопрос. Так, суммарный коэффициент рождаемости в

${ }^{18}$ Снижение суммарной рождаемости до 3,1 детей на женщину в 2045-2050 гг. и 1,8 детей на женщину в 2095 2100 гг.

${ }^{19}$ Суммарная рождаемости на уровне 5,7 детей на женщину. 
Алжире снизился с 6,8 в 1980 г. до 2,5 в 2000 г., в Иране - с 6,5 в 1982 г. до 2,0 в 2002 г. Причины столь быстрого снижения рождаемости в этих странах, и к тому же в весьма разных социальных условиях, исследованы недостаточно, но они включают быстрое снижение детской смертности и рост образовательного уровня. Уже можно сказать, что детская смертность в Нигерии снизилась до уровня, находящегося в пределах диапазона, характерного для Алжира и Ирана в то время, когда рождаемость начала там быстро снижаться (115 в 2015 г.).

Планирование семьи является рычагом, способным отчасти компенсировать недоразвитость других факторов демографического перехода. Контрацепция мало распространена в Нигерии (коэффициент охвата 10\%); в Алжире и Иране на старте быстрого падения рождаемости уже более четверти женщин использовали контрацепцию (в основном для управления календарем рождений), а к началу 2000-х годов охват увеличился до 50-60\%. Стал хрестоматийным пример Бангладеш, где сочетание быстрого снижения детской смертности с хорошо продуманной программой планирования семьи позволило в течение двух с половиной десятилетий снизить рождаемость вдвое, несмотря на неблагоприятный социально-экономический фон этой многонаселенной страны, входящей в группу наименее развитых стран мира.

Демографическая политика обладает большим потенциалом снижения рождаемости и предоставляет апробированные технические решения. Как показывает практика, мощные и универсальные программы планирования семьи могут инициировать контрацептивную революцию, которая реализует нарождающуюся потребность к ограничению числа детей в семье. На фоне своего региона Нигерия - богатая страна (ВВП на душу населения 2,5 тыс. долл. в постоянных ценах 2010 г.), хотя и с волатильной экономикой. Поступления в госбюджет из нефтяных доходов достаточны для финансирования широкомасштабной демографической программы без привлечения международных источников, отсутствует лишь политическая воля.

Образовательный уровень населения в Нигерии низок. Поскольку наиболее релевантные показатели образования не обеспечены данными по стране, приходится обратиться к информации о начальном образовании. Динамика охвата начальным образованием прерывиста: за 40-летний период численность учеников начальной школы росла в течение 31 года со средней скоростью 1,5 млн в год, а в течение 9 лет снижалась в среднем на 0,8 млн в год. В результате в стране далеко не обеспечивается охват обязательным начальным образованием. В то время как в Алжире и Иране достигнуты близкие к полному уровни охвата начальным образованием, в Нигерии около $20 \%$ детей не ходят в начальную школу, причем в течение последних 10-15 лет положение стагнирует. Как и в других странах, уровень образования является очень сильным предиктором рождаемости: женщины с начальным образованием имеют 6,1 ребенка, со средним - 4,6, а с образованием выше среднего - 3,1 ребенка [National Population ... 2014], но уровень образования выше начального редко встречается даже в городах и тем более в сельской местности. Распространение образования является одной из фундаментальных функций государства. Уже в силу этого и несмотря на бюджетные и кадровые ограничения рост образовательного уровня является эксплицитной и достижимой целью. Хотя деятельность в этой области никогда явно не формулируется как инструмент демографической политики, 
она имеет выраженное воздействие на репродуктивное поведение. Осознание серьезности демографической ситуации может вызвать повышение приоритетности вложений в образование.

В Африке к югу от Сахары родственные связи имеют важные для деторождения особенности. Родственники, в том числе дальние, являющиеся членами других домохозяйств и даже проживающие в других населенных пунктах, принимают активное и трудоемкое участие в уходе и воспитании детей, которые подчас годами живут в их семьях. Эта система ослабляет ресурсные ограничения детности и препятствует снижению рождаемости. Специально изменить ее нельзя ни технически, ни из-за политических соображений. Вероятно, урбанизация является необходимым и достаточным условием перехода к полностью нуклеарной семье. Подстегнуть урбанизацию могут позитивные и негативные факторы: ускорение роста городской экономики или рост аграрного перенаселения. Понятно, что первый путь предпочтительнее, но мальтузианские связи могут формировать второй. В любом случае управляемость урбанизацией невелика, следовательно, она вряд ли может быть инструментом антинаталистской политики.

Итак, в большей части развивающегося мира демографический взрыв отгремел, хотя абсолютные приросты населения во многих странах некоторое время еще будут увеличиваться. За исключением некоторых азиатских стран, демографический переход завершен или близок к завершению. Во многих странах сложился тип демографического поведения, не обеспечивающий воспроизводства населения; число таких стран растет. Вслед за развитыми странами Севера в одних таких развивающихся странах совсем скоро, в других несколько позже начнется убыль населения. Формируется группа развивающихся стран, где в повестку дня входит пронатализм. Демографический переход стал благом для Азии и Латинской Америки. Замедление роста населения через множество механизмов благоприятствовало экономическому росту и прогрессивным социальным преобразованиям. В Африке к югу от Сахары пробуксовывание демографического перехода усугубило и так чрезвычайно трудные проблемы национального развития.

Будущее африканских стран многовариантно, т.е. не полностью запрограммировано прошлой динамикой. Оно будет в большой мере определяться динамикой рождаемости, вектором и темпом модернизации. Даже «низкие» варианты демографического прогноза предполагают быстрый рост населения до конца столетия, а «верхние» вызывают опасения деструктивных социальных, экономических, экологических и политических последствий. Конечно, нельзя исключать, что модернизация в африканском контексте и в африканских формах может решительно ускорить демографический переход, а экономика, природные ресурсы и социальная среда смогут-таки абсорбировать длительный быстрый рост населения. В пользу этой перспективы говорит то, что к концу столетия, несмотря на огромный прирост населения в Африке к югу от Сахары, его плотность лишь достигнет нынешнего значения этого показателя по Западной Европе (в Нигерии - ненамного превысит). Но приходится признать, что кроме этого механистичного аргумента в пользу расхожего «антимальтузианского» подхода можно мало что предложить, по меньшей мере пока. 


\section{ЧЕГО МЫ НЕ ЗНАЕМ О ПЕРЕХОДЕ (ВМЕСТО ЗАКЛЮЧЕНИЯ)}

В обширной литературе о демографических процессах в странах Юга остаются значительные лакуны. Мало разработаны вопросы о том, как ускорить переход там, где это нужнее всего, и что произойдет, если этого не сделать. В 1970-е годы Отдел народонаселения Секретариата ООН готовил пионерские и вместе с тем всеобъемлющие публикации по этой проблематике [United Nations 1973], но с тех пор, отчасти из-за отсутствия политического заказа, а также потому, что за последние полвека в мире появилось множество высококвалифицированных исследовательских центров, работа в этой области практически прекратилась, а ограниченные ресурсы направляются в маргинальные, не имеющие практического значения проекты вроде анализа межпоколенных потоков ресурсов в самых развитых странах Юга, где демографический переход давно завершен: такие проекты дают тривиальные и практически незначимые результаты. Вместе с тем Отделом народонаселения разработаны и систематически обновляются релевантные глобальные базы данных по мировым демографическим оценкам и прогнозам, рождаемости, брачности, контрацепции и международным миграциям. Особенно важные вопросы находятся на пересечении системной и факторной теорий перехода, которые, повторим, в принципе не противоречивы, а взаимодополняемы. Стабилизация мирового населения если и произойдет, то очень и очень нескоро. Этому будут предшествовать длительный демографический взрыв в Африке к Югу от Сахары, депопуляция глобального Севера и сокращение численности населения ряда развивающихся стран, в том числе Китая. Ускорение демографического перехода в Африке - нетривиальная задача: для ее решения необходимо стимулировать сокращение детской смертности и сделать контрацепцию доступной всем и везде. Конечно, можно подступаться к этим задачам одновременно, главным образом потому, что программы планирования семьи дешевы. Однако следует иметь в виду, что есть пороги выживаемости детей, до достижения которых эффект таких программ будет невелик. Экстраполяция в будущее прошлых трендов снижения детской смертности должна инкорпорировать наблюдение о меньшей, по крайней мере в прошлом, роли родителей в этом процессе. Кроме этого, специфически африканские традиционные институты семьи являются мощным и резистентным препятствием трансформации репродуктивного поведения, особенно в сельской местности. Необходимо также добиться решительного прорыва в охвате образованием, в особенности среднего уровня. Между тем некоторые страны Африки к югу от Сахары попали в мальтузианскую западню: быстрый рост населения тормозит социально-экономическое развитие, без которого невозможно ускорение демографического перехода. Может ли в этих условиях восстановиться равновесие и какой ценой; каковы должны быть глобальные механизмы адаптации к быстрому росту населения в одном регионе; насколько и для кого станут приемлемыми такие механизмы в будущем эти системные вопросы только начинают осознаваться, хотя это будущее уже наступило.

Необходимость интеграции системно-динамического подхода с многофакторными моделями репродуктивного поведения не исчерпывается проблематикой переходного периода. Обширная литература о постпереходной рождаемости, в том числе о втором демографическом переходе, освещает более тонкую и, что еще важнее, новую структуру детерминации репродуктивного поведения. Однако однозначно понятного здесь не больше, 
чем еще не понятого. Меньшее понимание того, что происходит дома, чем процессов за океаном, имеет гносеологические корни. Резко уменьшается размах рождаемости: так, в группе постпереходных стран суммарная рождаемость колеблется от 1,1 детей на женщину на Тайване (1,3 в Китае, Боснии и Герцеговине, Греции, Испании, Молдавии и Португалии) до 2,0 в Новой Зеландии, в то время как в переходных и допереходных - от 2,1 в 10 развивающихся странах (включая Азербайджан, Малайзию, Турцию и Шри Ланку) до 7,4 в Нигере. При этом детерминация усложняется: увеличивается число потенциально важных, но трудноизмеряемых факторов. В постпереходных популяциях рождаемость полностью «отрывается» от детской смертности, а ее детерминация усложняется, включив новые факторы, часть которых плохо поддается измерению. Такая ситуация питает, в частности, разногласия о том, может ли вмешательство государства (в том числе, но не только, в форме демографической политики) развернуть тренд рождаемости. Еще меньше ясности по вопросу о принципиальной достижимости возвращения на заветный уровень 2,1 детей на женщину, не говоря о том, что дальнейшее старение населения вследствие увеличения продолжительности жизни потребует еще более высокой рождаемости.

В постпереходных странах достижение демографического равновесия предполагает перелом прошлой генеральной тенденции снижения рождаемости. При этом ее повышение до заветного уровня (2,1 детей на женщину) не гарантирует стабилизацию: если смертность продолжит сокращаться, то продолжится и старение населения, а с ним и рост числа смертей. С другой стороны, начинает осознаваться новая системная проблематика: какова будет репродуктивная реакция индивидов на длительную депопуляцию; сложится ли механизм популяционной адаптации или общество выработает другие адаптационные стратегии. Эта проблематика уже актуальна и надолго останется перспективной.

\section{ЛИТЕРАТУРА}

Вишневский А., Б. Денисов, В. Сакевич (2017). Контрацептивная революция в России // Демографическое обозрение 1: 6-34. URL: https://demreview.hse.ru/2017-1/206922700.html (дата обращения: 01.04.2017).

Вишневский А.Г. (2005). Демографическая революция. // А.Г. Вишневский. Избранные демографические труды. 1. Демографическая теория и демографическая история. М.: Наука: 3-214. URL: http:// http://demoscope.ru/weekly/knigi/dem_revol/dem_revol.html (дата обращения: 15.05.2016).

Вишневский А.Г. (2014). Демографическая революция меняет репродуктивную стратегию вида Homo sapiens // Демографическое обозрение. (1)1: 6-33. URL:

https://demreview.hse.ru/2014--1/120991102.html (дата обращения: 18.09.2016).

Демографическая модернизация России (2006). / Под ред. А.Г. Вишневского. М.: Новое Издательство. 602 с.

Иванов С. (1982). Развивающиеся страны: демографический взрыв. М.: Знание. 64 с.

Иванов С. (2010). Демографические факторы изменения климата // Сперо. 13: 11-118. URL: http://spero.socpol.ru/docs/N13_2010_08.pdf (дата обращения: 02.03.2016). 
Иванов С. (2011). Снижение рождаемости в странах Юга: политика вокруг политики // Экономический журнал Высшей школы экономики. 12: 565-582. URL: https://ej.hse.ru/2011-15-4/49834710.html (дата обращения: 02.03.2016).

Иванов С. (2013). Демография современного мира // Мировая экономика в начале XXI века / Под ред. А. Автономова, А. Бугрова, Л. Григорьева, С. Караганова, Е. Хесина. М.: ДиректМедиа: 336-373.

Иванов С. (2015). Проблемы народонаселения в международных отношениях // Современная наука о международных отношениях за рубежом. Хрестоматия в трех томах / Под общ. ред. И.С. Иванова. II. М.: Российский Совет по международным делам: 854-875.

Иванов С. (2017). Демографический взрыв: динамика, проблемы, решения // Мировая экономика и международные отношения. 61(7): 15-26.

Омран А.Р. (1977). Эпидемиологический аспект теории естественного движения населения // Проблемы народонаселения. О демографических проблемах стран Запада / Под ред. Д.И. Валентея, А.П. Судоплатова. М.: Прогресс: 57-91.

Bongaarts J., S.W. Sinding (2009). A response to critics of family planning programs // International perspectives on sexual and reproductive health. 33 (1). URL: https://www.guttmacher.org/journals/ipsrh/2009/03/response-critics-family-planningprograms (дата обращения: 15.03.2017).

Caldwell J. (1982). Theory of fertility decline. London: Academic press. 306 p.

Caldwell J. (2001). The globalization of fertility behavior // Global fertility transition, supplement to population and development review. 27: 93-115.

Caldwell J.C. (1980). Mass education as a determinant of the timing of fertility decline // Population and development review. 6(2): 225-255.

Dickeman M. (1975). Demographic consequences of infanticide in man // Annual Review of Ecology and Systematics 6: 100-132.

Galway K., B. Wolff, R. Sturgis (1987). Child survival: risks and the road to health. Report prepared by the Institute for resource development for the U.S. Agency for international development. $93 \mathrm{p}$.

Heer D.M., H.J. Wu (1975). The separate effects of individual child loss, perception of child survival and community mortality level upon fertility and family planning in rural Taiwan with comparison data from urban Morocco // CICRED Seminar on Infant mortality in relation to the level of fertility (Thailand, Bangkok, 6-12 May, 2001). Paris: CICRED: 203229.

Hirschman C. (1994). Why fertility changes // Annual review of sociology. 20: 203-233.

Horlacher D., S. Ivanov, A. Kvasha, R. Salas, A. Sudoplatov, D. Valentei (1986). Population and socio-economic development / R. Salas, D. Valentei, eds. Moscow: Progress publishers. $187 \mathrm{p}$.

Ivanov S. (1982). Razvivayushchiesya strany: demograficheskiy vzryv [Developing countries: the population bomb]. Moscow: Znanie. $64 \mathrm{p}$.

Ivanov S. (2010). Demographic and economic factors of labour supply: long-term projections and policy options for France, Germany, Italy and the United Kingdom // Vienna yearbook of population research. URL: 
http://www.oeaw.ac.at/vid/publications/VYPR2009/abstract_ivanov_demographic_and_econ omic_factors.html (дата обращения: 01.07.2016).

Jejeebhoy S.J. (1998). Women's education, autonomy and reproductive behaviour: experience from developing countries. Oxford : Clarendon press. 306 p.

Landry A. (1909). Les trois théories principales de la population // Scientia. 6(11): 2-39.

Landry A. (1936). La révolution démographique : Études et essais sur les problèmes de la population. Paris : INED-presses Universitaires de France. URL:

https://books.google.ru/books?id=NxW2ajK9hGEC\&printsec=frontcover\&hl=ru\&source=gb s_ge_summary_r\&cad=0\#v=onepage \&q\&f=false (accessed 02.09.2016) (дата обращения: 12.12.2016).

Lloyd C.B., C.E. Kaufman, P. Hewett (2000). The spread of primary schooling in Sub-Saharan Africa: implications for fertility change // Population and development review. 26(3): 483515.

Lloyd C.B., S. Ivanov (1988). The effects of improved child survival on family planning practice and fertility // Studies in family planning. 19(3): 141-162.

McNicoll (1986). Adaptation of social systems to changing mortality regimes. Consequences of mortality trends and differentials // Population studies. 95: 13-19.

Meadows D.H., D.L. Meadows, J. Randers, W.W. Behrens III (1972). The limits to growth: a report for the Club of Rome's project on the predicament of mankind. Washington D.C.: A potomac associate book. 205 p. URL: http://www.donellameadows.org/wpcontent/userfiles/Limits-to-Growth-digital-scan-version.pdf (дата обращения: 02.04.2016).

Meadows, D.J. Randers, D. Meadows (2004). A synopsis: limits to growth: the 30-year update. White river junction: Chelsea green publishing. URL: http://donellameadows.org/archives/asynopsis-limits-to-growth-the-30-year-update/ (дата обращения: 25.08.2017).

Montgomery M.R., C.B. Lloyd (1999). Excess fertility, unintended births, and children's schooling // Critical perspectives on schooling and fertility in the developing world / C.H. Bledsoe, J. Casterline, J.A. Johnson-Kuhn, J.G. Haaga, eds. Washington, DC: The National Academies press: 216-266.

Montgomery M.R., M. Arends-Kuenning, C. Mete (2000). The quantity-quality transition in Asia / C.Y. Cyrus Chu, R. Lee, eds. // Population and economic change in East Asia. Supp. to Population and development review. 26: 223-256.

National Population Commission - Nigeria and ICF International (2014). Nigeria demographic and health survey 2013. Abuja, Nigeria, and Rockville, Maryland, USA: NPC and ICF International. 538 p. URL: https://dhsprogram.com/pubs/pdf/FR293/FR293.pdf (дата обращения: 10.05.2017)

Notestein F. (1945). Population - the long view // Food for the world / T.W. Schultz, ed. Chicago: Chicago university press: $37-57$.

Park C.B., S.H. Khan, M.K. Choe (1979). The effect of infant death on subsequent fertility in Korea and the role of family planning // American journal of public health. 69: 557-565.

Preston S. H. (1980). Causes and consequences of mortality declines in less developed countries during the twentieth century // Population and economic change in developing countries / R.A. Easterlin, ed. University of Chicago press: 289-360. URL: http://papers.nber.org/books/east80-1 (дата обращения: 25.05.2017). 
Preston S.H. (1978). Introduction // The effects of infant and child survival on fertility / S.H. Preston, ed. New York: Academic press: 4-20.review of ecology and systematics. 6: 100$\neg 132$.

Rizk I.A., C.S. Stokes, M.R. Nelson (1982). The influence of individual and community-level child mortality on fertility in Egypt // Studies in comparative international development. Summer: 17(2):74-86.

Schultz T.P. (1976). Interrelationships between mortality and fertility // Population and development: the search for selective interventions / R.G. Ridker, ed. Baltimore: Johns Hopkins university press: $239 \neg-289$.

Scrimshaw S.C.M. (1983). Infanticide as deliberate fertility regulation // Determinants of fertility in developing countries / R.A. Bulatao, R.D. Lee, eds. 2. New York: Academic press: $245-266$.

Shorter E. (1977). The making of the modern family. New York: Basic books. 369 p.

Singh C., J.E. Darroch, L.S. Ashford (2014). Adding it up: the costs and benefits of investing in sexual and reproductive health 2014. Guttmacher Institute. URL: https://www.guttmacher.org/report/adding-it-costs-and-benefits-investing-sexual-andreproductive-health-2014 (дата обращения: 10.06.2017).

Thompson B. (1975). Some demographic factors illustrated in a Gambia village // Population growth and socio-economic change in West Africa / J. Caldwell, ed. New York: Columbia university press: $516-526$.

Thompson W. (1929). Population // American journal of sociology. 34(6): 959-979.

UNFPA (2014). United Nations Population Fund. UNFPA Global interventions and action plan, 2014-2017. New York: UNFPA.

United Nations (1973). Determinants and consequences of population trends: new summary of findings of interaction of demographic, economic and social factors. New York: United Nations.

United Nations (1987). Family building by fate or design. A study of relationships between child survival and fertility. ST/ESA/SER.R/74

United Nations (2003). Partnership and reproductive behaviour in low-fertility countries.

United Nations (2015). World population policies database. URL: https://esa.un.org/PopPolicy/about_database.aspx (дата обращения: 12.06.2017).

United Nations (2016). World contraceptive use 2016 (POP/DB/CP/Rev2016). URL: http://www.un.org/en/development/desa/population/publications/dataset/contraception/wcu2 016.shtml (дата обращения: 18.05.2017)

United Nations (2017). World Population prospects: the 2017 revision, DVD edition. URL: https://esa.un.org/unpd/wpp/Download/Standard/Population/ (дата обращения: 15.07.2017).

United States National Security Council (1974). Implications of worldwide population growth for US Security and overseas interests: national security study memorandum 200.

Washington, D.C. URL: http://pdf.usaid.gov/pdf_docs/PCAAB500.pdf (дата обращения: 10.04.2017).

Watkins S.C. (1991). From provinces into nations: demographic integration in Western Europe, 1870-1960. Princeton: Princeton university press. 254 p. 


\title{
DETERMINANTS OF THE DEMOGRAPHIC TRANSITION IN THE GLOBAL SOUTH
}

\section{SERGUEY IVANOV}

\begin{abstract}
All countries of the global North completed the demographic transition; most of them are on the verge of imminent depopulation. Over the past two decades, they have been joined by three dozen countries of the global South (including China) with an aggregate population of 1.5 billion. Some developing countries of different continents (i.e. India) are in advanced transition phases, while in sub-Saharan Africa (in particular Nigeria) fertility remains at a very high level. Demographic explosion in the region will not be contained soon and by the end of the century its population may increase by another 1.8-4.5 billion people, which is fraught with destructive consequences. Reducing child mortality and modernizing the way of life promotes proactive numerical goal setting and forms the mechanisms for adapting the birth rate to the background level and individual experience of child loss, and also limits fecundity. This transformation creates the conditions for fertility decline. The downward trend depends on the dynamics of the number of desired (surviving) children and the possibilities of realizing this desire. In turn, the procreative goal is a function of socio-economic factors, including education, employment, urbanization, and also of not always quantifiable institutional and environmental conditions. Modern contraception provides effective means for achieving reproductive goals. The stunting of the demographic transition in many sub-Saharan countries is caused by the unfavorable values of all factors of fertility, and the continuation of the demographic explosion is likely to lead to grave consequences.
\end{abstract}

Keywords: demographic transition, population growth, child mortality, fecundity, reproductive behavior, insurance behavior, replacement behavior, demographic equilibrium, fertility, contraception, family planning, education, urbanization, sub-Saharan Africa.

SERguey F. Ivanov (serguey.ivanov@yandex.ru), IndEPENDENT EXPERT, Russia.

DATE RECEIVED : MARCH 2017.

\section{REFERENCES}

Bongaarts J., S.W. Sinding (2009). A response to critics of family planning programs // International perspectives on sexual and reproductive health. 33 (1). URL:

https://www.guttmacher.org/journals/ipsrh/2009/03/response-critics-family-planningprograms (accessed: 15.03.2017).

Caldwell J. (1982). Theory of fertility decline. London: Academic press. 306 p.

Caldwell J. (2001). The globalization of fertility behavior // Global fertility transition, supplement to population and development review. 27: 93-115.

Caldwell J.C. (1980). Mass education as a determinant of the timing of fertility decline // Population and development review. 6(2): 225-255.

Demograficheskaya modernizatsiya Rossii, 1900-2000 [Demographic modernization in Russia, 1900-2000] / A.G. Vishnevsky, ed. Moscow: Novoe Izdatel'stvo: 601 p.

Dickeman M. (1975). Demographic consequences of infanticide in man// Annual review of ecology and systematics. 6: 100-132.

Galway K., B. Wolff, R. Sturgis (1987). Child survival: risks and the road to health. Report prepared by the Institute for resource development for the U.S. Agency for international development. $93 \mathrm{p}$. 
Heer D.M., H.J. Wu (1975). The separate effects of individual child loss, perception of child survival and community mortality level upon fertility and family planning in rural Taiwan with comparison data from urban Morocco // CICRED Seminar on Infant mortality in relation to the level of fertility (Thailand, Bangkok, 6-12 May, 2001). Paris: CICRED: 203229.

Hirschman C. (1994). Why fertility changes // Annual review of sociology. 20: 203-233.

Horlacher D., S. Ivanov, A. Kvasha, R. Salas, A. Sudoplatov, D. Valentei (1986). Population and socio-economic development / R. Salas, D. Valentei, eds. Moscow: Progress publishers. 187 p.

Ivanov S. (1982). Razvivayushchiesya strany: demograficheskiy vzryv [Developing countries: the population bomb]. Moscow: Znanie. $64 \mathrm{p}$.

Ivanov S. (2010). Demograficheskie faktory izmeneniya klimata [The demographic factors of climate change] // Spero [Spero]: 13: 11-118. URL: http://spero.socpol.ru/docs/N13_2010_08.pdf (accessed: 02.03.2016).

Ivanov S. (2010). Demographic and economic factors of labour supply: long-term projections and policy options for France, Germany, Italy and the United Kingdom // Vienna yearbook of population research. URL:

http://www.oeaw.ac.at/vid/publications/VYPR2009/abstract_ivanov_demographic_and_econ omic_factors.html (accessed: 01.07.2016).

Ivanov S. (2011). Snizhenie rozhdaemosti v stranakh Yuga: politika vokrug politiki [Ferility decline in the countries of the South: poltics around policies] // Ekonomicheskiy zhurnal Vysshey shkoly ekonomiki [Economic journal of the Higher school of economics]. 12: 565582. URL: https://ej.hse.ru/2011-15-4/49834710.html (accessed: 02.03.2016).

Ivanov S. (2013). Demografiya sovremennogo mira [Demography of the contemporary world] // Mirovaya ekonomika v nachale XXI veka [World economy at the onset of the XXI century / A. Avtonomov, A. Bugrov, L. Grigor'ev, S. Karaganov, E. Khesin, eds. Moscow: DirektMedia: 336-373.

Ivanov S. (2015). Problemy narodonaseleniya v mezhdunarodnykh otnosheniyakh [Population problems in international relations] // I.S. Ivanov, ed. Sovremennaya nauka o mezhdunarodnykh otnosheniyakh za rubezhom. Khrestomatiya v trekh tomakh [Modern science on international relations abroad. Reader in three volumes]. II Moscow: Rossijskij Sovet po mezhdunarodnym delam: 854-875.

Ivanov S. (2017). Demograficheskiy vzryv: dinamika, problemy, resheniya [Demographic explosion: dynamics, problems, solutions] // Mirovaya ekonomika i mezhdunarodnye otnosheniya [World economy and international relations]. 61(7): 15-26.

Jejeebhoy S.J. (1998). Women's education, autonomy and reproductive behaviour: experience from developing countries. Oxford: Clarendon press. 306 p.

Landry A. (1909). Les trois théories principales de la population // Scientia. 6(11): 2-39.

Landry A. (1936). La révolution démographique: Études et essais sur les problèmes de la population. Paris: INED-presses Universitaires de France. URL:

https://books.google.ru/books?id=NxW2ajK9hGEC\&printsec $=$ frontcover\&hl=ru\&source $=\mathrm{gb}$ s_ge_summary_r\&cad $=0 \# \mathrm{v}=$ onepage $\& \mathrm{q} \& \mathrm{f}=$ false $($ accessed 02.09 .2016$)$ (accessed: 12.12.2016). 
Lloyd C.B., C.E. Kaufman, P. Hewett (2000). The spread of primary schooling in Sub-Saharan Africa: implications for fertility change // Population and development review. 26(3): 483515.

Lloyd C.B., S. Ivanov (1988). The effects of improved child survival on family planning practice and fertility // Studies in family planning. 19(3): 141-162.

McNicoll (1986). Adaptation of social systems to changing mortality regimes. Consequences of Mortality trends and differentials // Population studies. 95: 13-19.

Meadows D.H., D.L. Meadows, J. Randers, W.W. Behrens III (1972). The limits to growth: a report for the Club of Rome's project on the predicament of mankind. Washington D.C.: A potomac associate book. 205 p. URL: http://www.donellameadows.org/wpcontent/userfiles/Limits-to-Growth-digital-scan-version.pdf (accessed: 02.04.2016).

Meadows, D.J. Randers, D. Meadows (2004). A synopsis: limits to growth: the 30-year update. White river junction: Chelsea green publishing. URL: http://donellameadows.org/archives/asynopsis-limits-to-growth-the-30-year-update/ (accessed: 25.08.2017).

Montgomery M.R., C.B. Lloyd (1999). Excess fertility, unintended births, and children's schooling // Critical perspectives on schooling and fertility in the developing world / C.H. Bledsoe, J. Casterline, J.A. Johnson-Kuhn, J.G. Haaga, eds. Washington, DC: The National Academies press: 216-266.

Montgomery M.R., M. Arends-Kuenning, C. Mete (2000). The quantity-quality transition in Asia / C.Y. Cyrus Chu, R. Lee, eds. // Population and economic change in East Asia. Supp. to Population and development review. 26: 223-256.

National Population Commission - Nigeria and ICF International (2014). Nigeria demographic and health survey 2013. Abuja, Nigeria, and Rockville, Maryland, USA: NPC and ICF International. 538 p. URL: https://dhsprogram.com/pubs/pdf/FR293/FR293.pdf (accessed: 10.05.2017)

Notestein F. (1945). Population - the long view // Food for the world / T.W. Schultz, ed. Chicago: Chicago university press: $37-57$.

Omran A.R. (1977). Epidemiologicheskiy aspekt teorii yestestvennogo dvizheniya naseleniya [Epidemiological aspect of the theory of natural population growth] // D.I. Valenteia, A.P. Sudoplatova, eds. Problemy narodonaseleniya. O demograficheskikh problemakh stran Zapada [Problems of population. On the demographic problems of the Western countries]. Moscow: Progress: 57-91. (Translated from: Omran A.R (1971). The epidemiological transition: a theory of the epidemiology of population change // The milbank memorial fund quarterly. 49 (4):509-538.)

Park C.B., S.H. Khan, M.K. Choe (1979). The effect of infant death on subsequent fertility in Korea and the role of family planning // American journal of public health. 69: 557-565.

Preston S. H. (1980). Causes and consequences of mortality declines in less developed countries during the twentieth century // Population and economic change in developing countries / R.A. Easterlin, ed. University of Chicago press: 289-360. URL: http://papers.nber.org/books/east80-1 (дата обращения 25.05.2017).

Preston S.H. (1978). Introduction // The effects of infant and child survival on fertility / S.H. Preston, ed. New York: Academic press: 4-20.

Rizk I.A., C.S. Stokes, M.R. Nelson (1982). The influence of individual and community-level child mortality on fertility in Egypt // Studies in comparative international development. Summer: 17(2):74-86. 
Schultz T.P. (1976). Interrelationships between mortality and fertility // Population and development: the search for selective interventions / R.G. Ridker, ed. Baltimore: Johns Hopkins university press: $239 \neg-289$.

Scrimshaw S.C.M. (1983). Infanticide as deliberate fertility regulation // Determinants of fertility in developing countries / R.A. Bulatao, R.D. Lee, eds. 2. New York: Academic press: 245-266.

Shorter E. (1977). The making of the modern family. New York: Basic books. 369 p.

Singh C., J.E. Darroch, L.S. Ashford (2014). Adding it up: the costs and benefits of investing in sexual and reproductive health 2014. Guttmacher Institute. URL: https://www.guttmacher.org/report/adding-it-costs-and-benefits-investing-sexual-andreproductive-health-2014 (accessed: 10.06.2017).

Thompson B. (1975). Some demographic factors illustrated in a Gambia village // Population growth and socio-economic change in West Africa / J. Caldwell, ed. New York: Columbia university press: $516-526$.

Thompson W. (1929). Population // American journal of sociology. 34(6): 959-979.

UNFPA (2014). United Nations Population Fund. UNFPA Global interventions and action plan, 2014-2017. New York: UNFPA.

United Nations (1973). Determinants and consequences of population trends: new summary of findings of interaction of demographic, economic and social factors. New York: United Nations.

United Nations (1987). Family building by fate or design. A study of relationships between child survival and fertility. ST/ESA/SER.R/74

United Nations (2003). Partnership and reproductive behaviour in low-fertility countries.

United Nations (2015). World population policies database. URL: https://esa.un.org/PopPolicy/about_database.aspx (accessed: 12.06.2017).

United Nations (2016). World contraceptive use 2016 (POP/DB/CP/Rev2016). URL: http://www.un.org/en/development/desa/population/publications/dataset/contraception/wcu2 016.shtml (accessed: 18.05.2017)

United Nations (2017). World Population prospects: the 2017 revision, DVD edition. URL: https://esa.un.org/unpd/wpp/Download/Standard/Population/ (accessed: 15.07.2017).

United States National Security Council (1974). Implications of worldwide population growth for US Security and overseas interests: national security study memorandum 200. Washington, D.C. URL: http://pdf.usaid.gov/pdf_docs/PCAAB500.pdf (accessed: 10.04.2017).

Vishnevsky A., B. Denisov, V. Sakevich(2017). Kontratseptivnaya revolyutsiya v Rossii [Contraceptive revolution in Russia] // Demograficheskoe obozrenie [Demographic review]. URL: https://demreview.hse.ru/2017--1/206922700.html (accessed: 01.04.2017).

Vishnevsky A.G. (2005). Demograficheskaya revolyutsiya [Demographic revolution] // A.G. Vishnevsky. Izbrannye demograficheskie trudy [Selected demographic works]. 1. Demograficheskaya teoriya i demograficheskaya istoriy [Demographic theory and demographic history]. Moscow: Nauka: 3-214. URL: http:// http://demoscope.ru/weekly/knigi/dem_revol/dem_revol.html (accessed: 15.05.2016).

Vishnevsky A.G. (2014). Demograficheskaya revolyutsiya menyaet reproduktivnuyu strategiyu vida Homo sapiens [The demographic revolution is changing the reproductive strategy of 
Homo sapiens] // Demograficheskoe obozrenie [Demographic review]. (1)1: 6-33. URL: https://demreview.hse.ru/2014--1/120991102.html (Translated into english: Vishnevsky A. (2014). The demographic revolution is changing the reproductive strategy of Homo sapiens // Demographic review. English selection: 3-24. URL: https://demreview.hse.ru/en/2014-5/171536325.html (accessed: 18.09.2016).

Watkins S.C. (1991). From provinces into nations: demographic integration in Western Europe, 1870-1960. Princeton: Princeton university press. 254 p. 